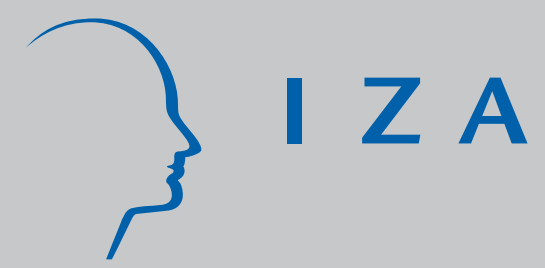

IZA DP No. 8880

Wish You Were Here? Quasi-Experimental Evidence on the Effect of Education on Attitude toward Immigrants

Beatrice d'Hombres

Luca Nunziata

February 2015

Forschungsinstitut zur Zukunft der Arbeit Institute for the Study of Labor 


\title{
Wish You Were Here? Quasi-Experimental Evidence on the Effect of Education on Attitude toward Immigrants
}

\author{
Beatrice d'Hombres \\ CRIE, JRC, European Commission \\ Luca Nunziata \\ University of Padua \\ and IZA
}

\section{Discussion Paper No. 8880 \\ February 2015}

\author{
IZA \\ P.O. Box 7240 \\ 53072 Bonn \\ Germany \\ Phone: +49-228-3894-0 \\ Fax: +49-228-3894-180 \\ E-mail: iza@iza.org
}

Any opinions expressed here are those of the author(s) and not those of IZA. Research published in this series may include views on policy, but the institute itself takes no institutional policy positions. The IZA research network is committed to the IZA Guiding Principles of Research Integrity.

The Institute for the Study of Labor (IZA) in Bonn is a local and virtual international research center and a place of communication between science, politics and business. IZA is an independent nonprofit organization supported by Deutsche Post Foundation. The center is associated with the University of Bonn and offers a stimulating research environment through its international network, workshops and conferences, data service, project support, research visits and doctoral program. IZA engages in (i) original and internationally competitive research in all fields of labor economics, (ii) development of policy concepts, and (iii) dissemination of research results and concepts to the interested public.

IZA Discussion Papers often represent preliminary work and are circulated to encourage discussion. Citation of such a paper should account for its provisional character. A revised version may be available directly from the author. 
IZA Discussion Paper No. 8880

February 2015

\section{ABSTRACT \\ Wish You Were Here? Quasi-Experimental Evidence on the Effect of Education on Attitude toward Immigrants}

We use European Social Survey and Labour Force Survey data to estimate the causal effect of education on European natives' opinion toward immigration exploiting reforms in compulsory education in Europe in the 1960s through the 1990s. Our findings show that higher education leads to a more positive attitude toward immigrants. We also investigate the mechanisms behind the effect of education on attitudes by evaluating both economic and non-economic channels. We find that higher education places individuals in occupations that are less exposed to the negative externalities of migration, although not in sectors/occupations where the share of migrants is necessarily smaller, suggesting that migrants and low-educated natives are complementary rather than substitutes in the labour market. In addition, education alters values and the cognitive assessment of the role of immigration in host societies, with a positive effect on tolerance of diversity and a positive effect on the assessment of immigration's role in host countries. Our findings suggest that education as a policy instrument can increase social cohesion in societies that are subject to large immigration flows.

JEL Classification: immigration, attitude towards immigrants, perception, education, compulsory education reforms

Keywords: $\quad$ 120, J61, J15

Corresponding author:

Luca Nunziata

Department of Economics

University of Padua

Via del Santo 33

35121 Padua

Italy

E-mail: luca.nunziata@unipd.it

\footnotetext{
* We are grateful for comments and suggestions from seminar participants at the "European Society for Population Economics" conference in Bern; the Second Lisbon Research Workshop, "Economics, Statistics and Econometrics of Education"; and the "International Workshop on Applied Economics of Education" in Catanzaro. The usual disclaimer applies.
} 


\section{Introduction}

Well documented anti-immigration sentiments in Europe help to explain the surge of xenophobic political movements in many European countries. Indeed, as the product of a long-lasting increase in labour flows across countries, immigration is likely to be increasingly at the centre of the political debate in Europe and elsewhere.

Recent empirical findings show how the attitude toward foreigners in host countries depends on both economic and non-economic factors. Some authors highlight how natives feel threatened by the competition in the labour market that arises from immigration (Scheve and Slaughter, 2001; Mayda, 2006), while other authors stress the importance of non-economic factors, such as racial intolerance (Dustmann and Preston, 2001), and how both kinds of factors play a significant role (Jack Citrin and Wong, 1997; O’Rourke and Sinnott, 2006; Hainmueller and Hiscox, 2010). Dustmann and Preston (2007) suggest that welfare concerns play a more important role than labour market concerns, and that racial and cultural prejudices relate primarily to immigrants from different ethnic backgrounds.

Therefore, one of today's policy-makers' more challenging tasks is to reconcile the well documented benefits of immigration for the host country's economy (OECD, 2013) and the asylum seekers' humanitarian urgencies, with the costs in terms of social cohesion, especially among low-skilled natives, who are believed to suffer the most from increasing competition in the labour market and increasing competition for welfare benefits.

Education may play a role in addressing this issue. Education may increase the labour market complementarity between natives and immigrants, consolidating the native workers' labour market position and protecting them from competition from immigrants. Education could also provide more cognitive ability with which to interpret the migration phenomenon in its entirety, enabling native workers to evaluate not only the costs but also the benefits that migrants bring to the host country. In addition, given its humanistic content, education may foster tolerant and humanitarian sentiments among the native population, combating cultural and racial prejudices. As a consequence, investment in education may result in a more open and favourable attitude toward foreign immigration and, ultimately, increased social cohesion in host countries. 
However, we still lack empirical insight into whether education has a causal impact on natives' attitude toward migrants. Higher education typically correlates with more positive attitudes toward immigrants (Card et al., 2009; Boeri, 2010). Hainmueller and Hiscox (2007) show that higher education correlates with more favourable attitudes toward foreigners, independent of the natives' labour market position, suggesting that more educated individuals are also less likely to have racial prejudices. However, such simple correlations are difficult to interpret as causal relationships, because unobserved dimensions of family background and omitted individual characteristics are likely to correlate with both education and attitude and may well account for these findings. For example, individual preferences for cultural diversity may correlate with both education and more favourable attitudes toward immigration. Therefore, it is difficult to elicit from such findings policy implications that point to education as a way to affect natives' attitudes toward migrants.

In this paper we aim to solve this identification problem and to estimate the causal effect of education on attitudes by using the reforms in compulsory education that took place in Europe in 1960s through the 1990s as a source of exogenous variation in education. To this end, using European Social Survey data from 2002 to 2010 and Eurostat Labour Force Survey data from the same period, we exploit the different birth cohorts' exposure to such reforms to instrument educational attainment.

Our IV findings show that education leads to a more positive attitude toward migrants, irrespective of their ethnicity and their continent of origin. The effect is large and robust to a variety of robustness checks. We discuss the mechanism behind the effect of education on attitudes by evaluating the relevance of economic and non-economic channels. Among economic channels we consider the role of labour market competition and the fiscal burden that some suppose attaches to immigration. Among the non-economic channels we test whether education conveys more tolerance of diversity, enhances awareness of the overall benefits of immigration for the host country, and/or develops general altruistic sentiments.

Our quasi-experimental analysis highlights that, while higher education allows individuals to be selected into better jobs and to be less dependent on welfare, thereby being less exposed to the supposed negative externalities of migration, immigrants and low-educated natives are more likely to be complementary than to be in competition with each other in the labour market. 
We also show that education affects attitudes even when individuals are more insulated from the negative externalities generated by immigration, like in the case of individuals who work in occupations and sectors where the share of migrants and the risk of becoming unemployed are low. Finally, we seek to determine whether education affects values and perceptions of the role of migrants in host countries and find that education has a significant impact on tolerance and on the cognitive perception of the beneficial effects of migration in the host country. This finding constitutes indirect evidence on the significant role of non-economic channels through which education affects attitudes toward immigrants. However, we find no effect of education on altruism and taste for equality.

Our paper is organized as follows: section 2 presents the data, while section 3 introduces and discusses the research design. The empirical findings are discussed in section 4, with the OLS results presented in 4.1, the IV estimates in section 4.2 and the robustness checks in section 4.3. Section 4.4 presents a discussion of the economic and non-economic channels behind the effect of education on the natives' attitude toward migrants. Finally, section 5 concludes.

\section{Data}

Our empirical analysis is based on data drawn from the first five rounds of the European Social Survey (ESS henceforth), which were fielded between 2002 and 2010, and the European Union Labour Force Survey (EU-LFS henceforth), fielded in the same years. Our analysis focuses on the twelve Western European countries that are most likely to be destination countries for migrants: Belgium, Denmark, Germany, Finland, France, Greece, Italy, the Netherlands, Portugal, Spain, Sweden, and the United Kingdom. All countries but Italy and Greece participated in the five waves of the ESS; Italy participated in only the first two rounds, and Greece took part in four rounds.

The ESS contains nationally representative samples of individuals who are fifteen years old or older and are residents in private households, regardless of nationality, citizenship, or language. ${ }^{1}$ The survey contains questions about the socio-economic characteristics of the respondents and

\footnotetext{
${ }^{1}$ The sample size for each wave per country is around 1,500 .
} 
their households and detailed information on trust in institutions, values, identity, health, wellbeing, various aspects of civic and political participation, and attitude toward minority groups.

Since the focus of our study is to identify the causal effect of education on the attitude of European natives toward immigrants, our sample includes only individuals who are and whose parents are/were citizens of the country in which the ESS survey took place. We exclude individuals who are younger than age twenty-two or older than age eighty and those who report being engaged in full-time education. Summary statistics are reported in Table A1 in the Appendix.

The ESS asked three questions related to respondents' attitudes toward immigrants. The first question concerns whether the respondent thinks people of the same race or ethnic group of her country should be allowed to come to the country to live. ${ }^{2}$ Questions 2 and 3 are related to attitudes toward "people of different race or ethnic group" from that of the respondent's country and "people from the poorer countries outside Europe", respectively. Each of the three questions allows four possible answers, which we recoded so 1 means "allow none", 2 means "allow a few", 3 means "allow some", and 4 means "allow many". In other words, a higher value for each variable indicates a more favourable attitude toward immigrants.

\section{TABLES 1 AND 2 AROUND HERE}

Table 1 reports the average answer to each question by country whereas Figures 1, 2 and 3 map the percentage of respondents with a positive attitude toward immigrants. ${ }^{3}$ Table 2 reports the frequency of each response category as a fraction of the total for each country. People in the Nordic countries, particularly Swedish citizens, are most in favour of immigration, while Greeks and Portuguese are the most hostile to it.

\section{FIGURES 1, 2 AND 3 AROUND HERE}

Post-war historical differences in migration trends across Europe might explain these regional differences, at least in part. Greece and Portugal are relatively new to immigration, having

\footnotetext{
${ }^{2}$ The phrasing of the question is: "To what extent do you think (country) should allow people of the same race or ethnic group as most (country) people to come and live here ?", where (country) stands for the country where the respondent lives.

${ }^{3}$ Further summary statistics are available in the Appendix.
} 
experienced a large inflow of foreigners since the late 1990s in response to the countries' strong economic performances at the time. On the other hand, Northern and Central Europe's massive intake of foreign workers began in the 1950s in response to those countries' colonial links and/or labour shortages. Furthermore, Portugal recently experienced a massive inflow of migrants from Eastern European countries of diverse cultural and linguistic backgrounds, contrary to the earlier immigration waves that arrived from colonies. The figures across countries show that European citizens are generally less in favour of immigration from poorer countries outside Europe than they are of migrants who belong to the same cultural group of the majority of natives. Only in some countries is the attitude toward the three types of migrants similarly negative.

We also use the larger informative content of the EU-LFS in order to gather additional information on the concentration of migrants by country and sector of activity, as well as on the educational skills and labour market status of migrants relative to natives. ${ }^{4}$

As in most of the literature, we define the immigrant population as those individuals who reside in the host country but were born in another country. This definition is preferred to the one based on citizenship, as it limits the distortions that can occur from differences in the legislation that governs the various countries' naturalisation processes.

Tables 3 and 4 present a set of summary statistics on the characteristics of immigrants and natives in terms of their education, sectors of activity, and types of occupation in each country in the sample. The figures were computed using data from the 2009-2010 waves of the EU-LFS.

\section{TABLES 3, 4 AND 5 AROUND HERE}

Table 3 displays some summary statistics on immigration by country. The share of migrants in each country varies from the low levels of Finland (3.4\%) and Portugal (6.5\%) to the higher levels of Belgium (16.6\%), France (13.6\%), Sweden (13.5\%), and the UK (12.6\%). The table also reports the ratio of the share of migrants with primary education to the share of natives with primary education and the same for tertiary education. Finally, the table reports the

\footnotetext{
${ }^{4}$ The EU-LFS, which is conducted in all EU Member States, samples around 2-3 percent of people aged fifteen and older in the target population and includes information on the respondents' labour market participation and other individual characteristics.
} 
ratio of unemployed migrants to unemployed natives and socio-economic differences between immigrants and natives in terms of household size, number of children, and income. The composition of migrants in terms of their educational and labour-market status varies substantially across countries. While in Germany the proportion of immigrants with primary education is more than double that of natives, the picture is reversed in Portugal and the UK. On the other hand, in all twelve countries the labour market status of immigrants compares unfavourably to that of the native-born.

Table 4 shows the distribution of migrants by sector of activity, defined at digit 1 level. The majority of immigrants tend to be hired by private households or to concentrate in the hotels and restaurants and construction sectors. The figures displayed in Table 5 confirm that migrants are more concentrated in elementary occupations.

\section{Research Design}

Education is likely to be endogenous in a model of attitude toward immigrants. Omitted variables related to family background and unobservable individual characteristics are likely to prevent the interpretation of simple OLS estimates as causal. As a result, the policy implications based on OLS findings may be misleading, as the findings may suggest that education is instrumental to changing natives' attitudes toward immigration when attitudes may just as well be predetermined and not necessarily affected by education.

We address the problem of the endogeneity of education by adopting a quasi-experimental identification strategy. More precisely, we exploit exogenous supply-side variations in schooling to identify the causal effect of education on attitudes toward immigrants. In the tradition of Angrist and Krueger (1991) and Brunello et al. (2009, 2013), we rely on exogenous variations in education that are caused by changes in compulsory-education legislation to instrument educational attainment. ${ }^{5}$

To this end, we have identified all reforms that affected the number of compulsory years of

\footnotetext{
${ }^{5}$ See Milligan et al. (2003), Orepoulos (2006), or Borgonovi et al. (2010) for other examples of papers that rely on a similar identification strategy.
} 
education in each of the twelve western countries included in the analysis. Each compulsoryeducation reform, the date when each reform occurred, the first cohort affected by each reform, and the change in the number of years of compulsory education attached to each reform is reported in the Appendix. The school reforms considered in this paper took place between 1947 and 1999, with the changes in the number of years of mandatory education varying between -1 to +4 years. The selected school reforms were implemented nationwide for all countries, and only in Finland and Germany were some reforms implemented at differing times across regions. We identified one reform per country, except for Portugal where we identify three reforms. ${ }^{6}$

Our research design consists of selecting the first birth cohorts that were affected by each reform and those cohorts who were the last to be subject to the pre-reform educational system. Each individual is assigned either to the pre-reform group (non-treated group) or to the post-reform group (treated group) according to their year of birth. We then instrument education with a dummy variable that equals one if the respondent belongs to the treated group and zero otherwise, and estimate the following equation:

$$
y_{i t}=\beta e d u c_{i t}+\lambda^{\prime} \mathbf{X}_{i t}+\mu_{c}+\mu_{t}+\varepsilon_{i t}
$$

where the dependent variable $y$ is a dummy variable that equals 1 (favourable attitude) if the answer to how many immigrants from the same race/ethnic group, different race/ethnic group, and poor countries should be allowed in the host country is "some" or "many" and 0 (non-favourable attitude) if the answer is "few" or "none". The covariates $X$ include demographic variables (age, gender), area of residence, and country-specific quadratic age trends to control for unobservable factors that may be confounded with the reform intervention. ${ }^{7} \mu_{c}$ are country dummies and $\mu_{t}$ are survey-year dummies. In the case of the UK and Germany, $\mu_{c}$ also includes major regional dummies (East Germany, Northern Ireland and Scotland fixed effects). Similarly to Brunello et al. (2009), equation 1 is estimated on a restricted sample of

\footnotetext{
${ }^{6}$ Most of the countries underwent several educational reforms in the last sixty years. The existing literature that relies on the same identification strategy has selected those reforms in compulsory education that are characterised by a sizeable increase in the number of years of education and for which it is possible to clearly identify first birth cohort affected by the reform. We follow the same criteria using the reforms considered in Brunello et al. (2009) and add Portugal that was originally missing from their analysis.

${ }^{7}$ Note that in the case of Portugal, for which three reforms are used, the quadratic age trends are countryreform-specific.
} 
treated and non-treated individuals born at most seven years before or after the first affected cohort. By restricting the sample, we control for confounding factors that may affect education and attitude, including broad cohort effects and schooling reforms other than those related to compulsory education that may affect treated and non-treated individuals differently. By considering only individuals born within this time bracket, we ensure that our respondents are comparable in terms of the possible confounding factors that may simultaneously affect attitude toward migrants and education. The robustness of our empirical findings to the choice of the $+/-7$ window is tested by estimating equation 1 using bandwidths of various length.

The validity of our identification strategy rests on the assumption that, conditional on the covariates included in equation 1 , the timing of the legislation change is not correlated with any other country or economic or social change, and that the change has no direct effects on attitudes toward immigrants. In order to ensure that such is the case, equation 1 includes country-specific quadratic birth cohort trends that control for contemporaneous changes in time-varying unobservable factors at the country level. ${ }^{8}$

In what follows we introduce our empirical findings, test the robustness of our results, and finally analyse the mechanisms behind the effect of education on attitudes.

\section{Empirical Findings}

\subsection{OLS and Probit Estimates}

Table 6 presents our OLS and Probit estimations, displaying the effect of education on attitudes on the full sample, that is, without restricting the sample to individuals born at a maximum of seven years after or before the first cohort affected by the reform. The results point to a statistically significant positive correlation between education and a positive attitude toward migrants, which is in line with the literature. Point estimates suggest that one additional year of education is associated with a 2.3 - 2.6 percentage point increase in the probability of having

\footnotetext{
${ }^{8}$ Our identification strategy resembles that of a local regression discontinuity approach, where the discontinuity is induced by the change in the number of years of compulsory education, and the individuals pre- and post-treatment within a certain time bracket are likely to be comparable.
} 
a positive attitude toward immigration. Our findings are consistent across all three measures of attitude, suggesting that education is correlated with increased positivity, no matter the type of immigration. Similar findings are obtained when the sample size is limited to the number of observations used in the IV estimations presented in section 4.2 (i.e., considering only individuals born at a maximum of seven years after or before the first cohort affected by each reform). Although the number of observations drops from 66,933 to 21,949, the estimated coefficients are basically unchanged. The table also shows the marginal effect of education, evaluated at average values of all regressors, which results from a Probit estimation on the restricted sample. Results are very close to those reported for the full sample and for the sample of individuals born at a maximum of seven years after or before the first cohort affected by each reform. In all cases the largest point estimate is between education and the attitude toward immigrants who belong to a different ethnic group. Comparable estimates are reported in Hainmueller and Hiscox (2007), whose study is also based on European countries.

The OLS and Probit findings should however be treated with caution since they may suffer from omitted variable bias. In what follows, we turn to the quasi-experimental setting introduced in section 3 in order to estimate the causal effect of education on attitudes.

\section{TABLE 6 AROUND HERE}

\subsection{Estimates}

Our IV findings, which exploit the exogenous reforms in compulsory education, are presented in Table 7 . The table reports the estimates for each indicator of attitude toward immigrants under alternative model specifications.

The first stage of our IV estimates consists of a regression of years of education on the exogenous treatment dummy that equals one for the first seven birth cohorts affected by each reform and zero otherwise. The results of the first-stage regressions are reported in Table 7 . The average increase in compulsory years of education as a result of the reforms is 0.35 years (around four months) of education, a finding that is in line with previous contributions in the literature. Brunello et al. (2009) find that a one-year increase in compulsory education increases actual 
educational attainment by $0.30-0.40$ years, while Brunello et al. (2013) report an impact of 0.42-0.57 years.

The Anderson-Kleibergen (AK) test rejects the null hypothesis that the model is underidentified. In addition, the F-statistics of the joint significance of the excluded instruments are well above the threshold of 10 indicated by Staiger and Stock (1997) as the criterion for testing for instrument weakness when the parameters are just identified.

The second stage IV coefficients displayed in Table 7 are positive and significant and much larger than the OLS estimates. One additional year of education increases the probability of having a favourable attitude toward immigrants of the same ethnic group by around 8.8 percentage points, which is almost four times as large as what was found with OLS. The effects associated with education are slightly larger when attitude toward migrants of other ethnic groups or from poorer countries is considered, being respectively equal to 9.7 and 10 percentage points.

Our estimations point to a sizeable causal effect of education on attitudes, suggesting that education may be an important channel through which policy makers can influence attitudes toward immigrants. Before investigating in more detail the mechanisms behind our findings, we test whether these findings survive a number of robustness checks, including changes in our specifications and a placebo test.

\subsection{Robustness checks}

\section{(A) Changes in Bandwidth}

Our baseline specification reported in Table 7 is estimated on a sample composed of individuals who were born up to seven years before or after the first cohort affected by each reform in compulsory schooling. In choosing the time window before and after the cut-off point, we face a trade-off between a larger sample size (associated with a longer window) and a higher degree of comparability between treated and non-treated individuals (associated with a shorter window). Table 7 also displays the estimates obtained by using bandwidths of $+/$ - five years and $+/$ - nine years. Our conclusions are not sensitive to a change in the size of the window surrounding the discontinuity. The first-stage effect of the reforms is always significant, and the 
effect of one additional year of education is close to our baseline estimates in the case of the +/five-year interval. The point estimates are slightly smaller when adopting the $+/$ - nine-year interval, possibly because the risk of omitted factors affecting our estimates increases as the time interval considered increases.

\section{(B) Overparameterisation}

To determine whether the inclusion of country-specific birth cohort trends may overparameterise our model, we exclude the trends from our specification and check how our results change with this omission (Table 7, column 4). All our results are still positive and statistically significant with a slight decrease in the size of the point estimates.

\section{TABLE 7 AROUND HERE}

\section{(C) Placebo Test}

In order to be sure that our first-stage findings are not generated by some random patterns in the data instead of the educational reforms, we conduct a placebo test based on artificial compulsory education reforms generated randomly from a uniform distribution over the interval 1947-1999. In order to mimic the actual reforms used for the IV estimates, we consider one reform per country, except for Portugal for which we simulate three reforms. In addition, all of the artificial reforms are countrywide except in countries where they were implemented regionally. Similar to our baseline estimates, the treated individuals are those born up to seven years after the first cohort affected by the artificial reform. The control groups are those born up to seven years before. As shown in Table 7, we find no effects of artificial reforms on education in the first-stage regressions, which result points to the validity of our identification strategy. In addition, when an artificial reform is used in the first stage, education has no effect on the attitude toward immigration. As a further check, we carried out some Monte Carlo simulations by estimating equation (1) 1000 times after having generated artificial reforms for each of these 1000 estimates. The type I error-that is, the probability of rejecting the null hypothesis that the coefficient associated with education is zero when the null is true-is below 
the 0.05 significance level for all three immigration opinion measures.

\section{(D) Sensitivity to Country Exclusions}

Finally, we determine whether the results depend on the inclusion of any particular country in the sample and the specific reforms implemented in that country alone. Table 8 reports our baseline IV estimate on a set of restricted samples, where we remove one country at a time. Our findings are robust to country exclusion and do not seem to depend on the inclusion of any particular country: the coefficients associated with education are always positive and significantly different from zero.

\section{TABLE 8 AROUND HERE}

Our IV estimates point to a significant causal effect of education on attitudes that is much larger than that found by OLS. Each additional year of education implies a 5 - 10 percentage point increase in the probability that an individual will report a favourable attitude toward immigrants. This finding may be driven by the high returns from education among compliers, that is, those who are affected most positively by compulsory education reforms. Therefore, the IV estimates reported here may be capturing a local average treatment effect (LATE) that is higher than the average treatment effect (ATE) when the returns on education are higher for compliers.

As shown in Table A6 in the Appendix, the exogenous change in the number of years of compulsory education after the implementation of the reforms varies substantially across countries. The compliers are especially concentrated among those with primary, lower secondary, or upper secondary education. The respondents with tertiary education are the less affected since one would expect that their educational attainment is less likely to have been influenced by the reform..$^{9}$

\footnotetext{
${ }^{9}$ This expectation is confirmed by the estimation of the first-stage regressions on sub-samples of respondents with tertiary education only or with upper secondary education at maximum. The effect of the instrument on educational attainment is large and statistically significant in the latter case and weak in the former case. (Not reported; results are available upon request).
} 
In our context, low- and medium-skilled individuals are more likely than others to be affected by some of the negative externalities of immigration. Therefore, our large IV effects may be explained by the increase in compulsory education affecting those individuals who are likely to have a negative opinion of the immigration phenomenon. This effect is precisely what policy makers would want to achieve in using education as a policy instrument to increase social cohesion in a society that is subject to large immigrant inflows.

\subsection{Why Does Education Affect Attitudes?}

The question concerning the factors that explain our findings remains: why does education affect attitudes? The estimated effect may be driven by economic channels, through a consolidation of the labour market position of native workers or by non-economic channels, such as a cognitive effect on the natives' understanding of the implications of immigration for host countries or an increase in the humanitarian sentiment or tolerance among natives. This section investigates the role of both economic and non-economic channels and provides some additional empirical analysis to clarify the most important factors behind our results.

\subsubsection{Economic Channels}

Starting with the economic channels, the real consequences of immigration flows on labour market dynamics are far from obvious, as the mixed findings in the literature suggest. For example, Borjas (2003) shows that immigration lowers the wages of competing workers in the US, whereas D'Amuri et al. (2010) and Ottaviano et al. (2013) find that immigration has little adverse effects on native wages and employment in Germany and the US.

As shown in Table 3, in all countries but Portugal and the UK, the share of migrants with primary (tertiary) education is higher (lower) than the corresponding proportion of natives, which suggests, that low-educated natives should feel more challenged by the arrival of immi-

grants. Furthermore, if respondents believe that migrants depress the wages of unskilled labour, educated natives, who hold higher-level, higher-paying jobs, could be even more favourable to immigration since migrants may constitute a source of cheap labour for production or domestic 
activities.

Scheve and Slaughter (2001) find that low-skilled native workers in the US are significantly more likely to prefer limiting immigrant inflows into the country, and the coefficient associated with education becomes insignificant when the sample is limited to individuals who are not in the labour force. This result is consistent with the assumption that immigration-related preferences are driven by the fear (or lack of fear) of labour-market competition. Cross-country analyses of the determinants of individual attitudes toward immigration (Mayda, 2006; O'Rourke and Sinnott, 2006) report similar findings: the coefficient associated with education becomes insignificant when the sample is restricted to individuals who are not in the labour force. Mayda (2006) and O'Rourke and Sinnott (2006) also find that, as the destination country's GDP per capita, a proxy for the natives' overall skill level, increases, the association between education and favourable attitudes toward immigrants also increases.

In addition to the aspects related to labour market competition, natives often perceive immigration as a fiscal burden. Low-educated immigrants usually have dimmer employment and earnings prospects than similarly educated natives, so these immigrants may presumably be perceived as likely to be dependent on the welfare system and as contributing less to its financing.

Recent EU-LFS figures (see Table 3) show that migrants compare unfavourably with natives in our set of countries: they are more likely to be unemployed, their households are generally larger, they have more children under age fourteen, and they are poorer than their native counterparts, so they are generally more likely to claim unemployment and family benefits than natives are. However, the long term fiscal consequences of migration are unclear, particularly in European countries characterised by aging populations (Rowthorn, 2008). For example, Dustmann and Frattini (2013) show that the immigration wave into the UK that followed the European community enlargement was composed of immigrants whose educational background and educational participation rate exceed that of natives, a circumstance that has translated into migrants' positive net contribution to the UK fiscal system.

As Facchini and Mayda (2012) discuss, if the economic adjustment to migration is made through additional progressive taxes, wealthy natives will bear much of the costs of migration, which 
should translate into more negative attitudes toward low-educated migrants. The opposite should happen if immigrants are highly educated. However, if the economic adjustment is achieved by reducing the quantity or quality of public services, then the low-educated natives, i.e. the most intensive users of public services, are more at risk of being hit the hardest by low-skilled migrant inflows.

A final channel related to economic factors has to do with social interaction. Because of their higher economic status, more educated natives may be less likely than those who are less educated to interact with migrants. For example, they may live in areas where immigrants are unlikely to be able to afford to live and to be included in the natives' social circles. A more positive attitude toward migrants may be the result of this social distance, along with the lower costs associated with migration for more educated individuals. In other words, immigration may be a phenomenon to which more educated individuals do not directly relate. This possibility is confirmed by the high level of hostility toward minorities in areas of the UK that are characterised by a high concentration of ethnic minorities (Dustmann and Preston, 2001).

\subsubsection{Non-Economic Channels}

Education can also affect attitudes through non-economic channels. First, education develops knowledge and cognitive abilities. Therefore, those who are more educated may be more aware of the benefits of immigration for the host country's economy. ${ }^{10}$

Education may also be a filter through which natives process the media coverage of immigration phenomena, enabling the more educated natives to distinguish between facts and uninformed rethoric. According to Facchini et al. (2009, 2013), the portrayal of tensions between natives and migrants by the media can have a feedback impact on natives' attitudes toward immigrants. Indeed, Fitzgerald et al. (2012) find that fear of crime is a predictor of one's attitude toward immigration in Germany, ${ }^{11}$ with a larger effect during election years, when the media's attention to the topic of immigration is at a high level. In such cases, more educated natives might be insensitive to misleading anecdotal stories on immigration.

\footnotetext{
${ }^{10}$ For example, Foged and Peri (2013) show how low-skilled immigration enhances natives' wage outcomes through complementarity.

${ }^{11}$ Similar findings are obtained by Nunziata (2015) on a sample of 16 western European destination countries.
} 
Education may also trigger more tolerance toward cultural differences. It is often argued that a sense of opposition toward immigration may be generated by the cultural diversities between the host country's natives and the immigrant population, with such differences being perceived as engendering social tensions (Dustmann and Preston, 2007) and undermining national identity. In this respect, the humanistic content of education in democratic countries like those under investigation here may inspire a more open and tolerant attitude toward individuals with differing lifestyles and cultural backgrounds, and a more humanitarian attitude in general. In other words, education may transmit not just knowledge but also a set of values. If this is the case, individuals with a higher level of education will be more favourable and open to immigration.

One final point regards the possibility that, despite the survey's being anonymous, self-reported opinions about immigration are affected by a form of social-desirability bias. This bias may affect our results if, for example, more educated respondents were inclined to disavow feelings of bigotry or intolerance even when those feelings are present. However, the literature on the topic suggests that this tendency is typical of individuals who need social recognition (Crowne and Marlowe, 1964), and it is unclear how this need correlates with education. In any case, even if education induced a "politically correct" stance that was not genuine, the desire to be politically correct may be an additional channel through which education increases social cohesion.

\subsubsection{Which Channels Are Behind Our Findings?}

Our results so far show that higher education increases the positivity of attitudes toward immigration. The magnitude of the coefficients associated with education varies little with the characteristics of the immigrant population, which suggests that economic concerns may not be the only channel at work. In this section we use our model to identify the underlying channels through which education affects attitudes.

\section{Are low skilled natives competing with immigrants on the labour market and/or for welfare benefits?}


We investigate to which extent attitudes toward immigrants is related to personal economic circumstances. Exposition to competition from migrants may be induced by being confined to weaker social and labour market statuses or lower skill jobs. Natives falling into these categories may find themselves more exposed to a negative labour market shock. They may then see migrants as potential competitors or construct a self-serving representation of the factors explaining their actual economic conditions in which migrants are attributed part of the blame. In addition, competition may take the form of an actual larger share of migrants in certain sectors and occupations. In this case the natives working in those sectors and occupations may perceive the presence migrants as an immediate threat, especially when unemployment associated to those sectors and occupations is high.

Table 9 shows the results of using our identification strategy to analyse whether and how education affects the respondents' labour market status. More precisely, we report the impact of education on the probability that an individual is unemployed, employed with a short-term contract, or dependent on the welfare system, defined as receiving unemployment benefits or any other social benefits as a main source of income (column 1). Table 9 also displays the impact of education on the probability that an individual works in a low-skilled occupation, classified as "workers and elementary occupations" (column 2). The individuals in these occupations are the most likely to compete with migrants in the labour market and as welfare recipients, given the migrants' characteristics reported in Table 3. As expected, a lower level of educational attainment increases the probability of being in both groups. One additional year of education reduces the likelihood that an individual is unemployed, employed with a short-term contract, or dependent on the welfare system by around 10.4 percentage points. Similarly, one additional year of education reduces the likelihood that an individual works (or worked in his or her last job if he or she is unemployed) in low-skill occupations by 8.3 percentage points.

Both sets of findings confirm the expected strong positive effect of education on labour market status. In other words, more education leads to a stronger position in the labour market and more insulation from negative economic shocks.

However, higher education does not seem to decrease the probability that an individual will work in combinations of sectors and occupations where the share of migrants is large. Table 9 shows the effect of education on the probability that an individual work (or have worked 
in his or her last job) in particular combinations of occupations (five broad categories) and sectors of activity (at the one-digit level) where there is a high concentration of immigrants. The concentration of immigrants by sector and occupation is calculated using the micro LFS surveys over the period 2002-2010. A sector/occupation combination is defined as having a high concentration of migrants if the migrants' penetration rate is above the share of migrants at country level. The estimates are not statistically significant (columns 3 to 6 ). This finding is robust to the adoption of a stricter definition of a highly penetrated sector/occupation or when we consider sectors that are characterised by a share of job seekers that is larger than the country average.

These results suggest that immigrants are not necessarily in competition with low-educated native workers on the labour market but may be complementary, as Foged and Peri (2013) claims.

\section{What is the impact of education on the attitudes of individuals who are insulated from competing immigrants?}

In order to investigate in more detail the role of non-economic factors, we must separate out the effect of economic elements. One strategy is to concentrate on natives who have a low level of exposure to the potential economic competition immigrants generate and test whether education still affects their attitude toward them. If such is the case, we may hypothesise the existence of additional non-economic factors behind our findings. Therefore, we re-estimate our baseline IV model to focus on a subsample of natives who work in combinations of sectors and occupations with a low concentration of competing immigrants and so have little exposure to economic competition. We already know from Table 9 that selection into these professions does not depend on education. ${ }^{12}$

\section{TABLES 9 AND 10 AROUND HERE}

Our empirical findings are reported in Table 10, where in column 1 our model is estimated on

\footnotetext{
${ }^{12}$ This latter finding is relevant to the validity of our empirical strategy since the sample of respondents who are insulated from immigrants' competition should include respondents with all levels of education and not only individuals with higher levels of education, for whom our instrument may be weak.
} 
the restricted sample excluding individuals who are working or have worked in their previous jobs (if they were unemployed at the time of the survey) in the four sectors of activity with the largest concentration of employed migrants in each country. As indicated by Table 4 these sectors may differ according to country, but they are typically related to construction, domestic activities, hotel and restaurants and real estate. The table also shows the results when considering only individuals who work or have worked in sectors/occupations (column 2) or occupations (column 3) with a share of participating migrants lower than the country average of migrants. Finally, the table shows the results of limiting the analysis to respondents who work in occupations and/or sectors with a low percentage of participating migrants or that are characterised by an unemployment rate below the country average (columns 4 and 5). ${ }^{13}$ All estimates point to a significant effect of education on attitudes toward migrants, even among individuals who should feel more insulated from economic competition, thus indicating that non-economic channels may also play a significant role in explaining the relationship between education and attitude toward immigrants. As an additional robustness check, we estimated our model on a sub-sample of individuals who work under open-ended contracts (not reported) and find again that education is significantly associated with a positive attitude toward immigrants.

\section{Indirect evidence on the non-economic channels through which education affects attitudes}

As argued above, the non-economic channels may operate through education's effect on beliefs and values and on the cognitive assessment of the beneficial role of migration in host countries. The ESS provides data on three relevant dimensions: altruism, preference for equal opportunity, and tolerance of diversity.

Therefore, we can provide additional evidence on the role of the non-economic factors that lie behind the relationship between education and attitude toward immigrants by examining the effect of education on each of these values and beliefs. Our findings are reported in Table 11. The estimates provide indirect evidence on the channels through which education affects attitudes.

\footnotetext{
${ }^{13}$ The country unemployment rate by occupation and sector is computed using LFS data and ESS information on the sector of activity for the previous jobs of all unemployed respondents.
} 
The dependent variable of the model estimated in column 1 is a measure of altruism, i.e. a dummy equal to one if the individual reports being "very much" like him to help others and care for others' wellbeing, and zero otherwise. In this case the effect of education is not statistically significant. Then the outcome variable is changed to a measure of preference for equality in column 2, where the dummy variable equals one if the individual reports that treating every person in the world equally and believing that everyone should have equal opportunities in life is "very much" what he or she thinks. Again, the effect of education is not statistically significant.

Finally, the model investigates the effect of education on aversion to discrimination (column 3), measured by a dummy variable that takes the value of one if the individual agrees or strongly agrees that gay men and lesbians should be free to live life as they wish, and zero otherwise. This representation of tolerance is of particular interest because it is, by definition, clear of economic implications, since gay men and lesbians represent diversity only in the sexual sphere and are not discriminated against for any economic reason. Here we do find a significant and positive effect of education on tolerance, as an additional year of education increases the probability that an individual will have a tolerant attitude toward diversity by 7.8 percentage points.

\section{TABLE 11 AROUND HERE}

In addition to influencing values and beliefs, education may affect the cognitive assessment of the role of immigration in host economies and societies, with a resulting more positive attitude toward immigrants. This suggestions is confirmed by the evidence in Table 11.

The dependent variables of the model in column 4 is a dummy variable equal to one if the individual believes that the country's cultural life is enriched by immigrants and zero otherwise. The dependent variable of the model in column 5 is equal to one when the respondent thinks that immigrants make the host country a better place to live, and zero otherwise. In both cases higher education induces a more positive assessment of the role of immigration in host countries.

Our last set of estimates confirm that the the association between education and favourable at- 
titudes toward immigrants may also be generated through non-economic channels, as suggested by the findings in Table 10. We find that an increase in education induces individuals to be more tolerant of diversity and have a more positive assessment of the impact of immigration in the host country. However, education does not affect altruism and the preference for equality.

In summary, tolerance of diversity and the cognitive assessment of the role of migrants in the host country seem to be relevant channels through which education affects attitudes.

\section{Concluding Remarks}

We exploit reforms in compulsory education in Europe from the 1960s through the 1990s in order to estimate the causal effect of education on European citizens' attitude toward immigrants. Our findings show that education leads to a more positive attitude toward migrants and that the role of education is much stronger than that found in simple OLS or Probit estimates. One additional year of education leads to a 5 - 10 percentage point higher probability to report a favourable attitude toward immigrants.

We also investigate the mechanism behind the effect of education on attitudes toward migrants by evaluating the effect of education through both economic and non-economic channels. We find that higher education selects individuals into occupations and statuses that are less exposed to the negative externalities of migration but also that education does not affect the likelihood that an individual will to work in sectors/occupations where the share of migrants is smaller. This finding is in line with previous findings in the literature that suggest job-complementarity between migrants and natives (Foged and Peri, 2013). In addition, the effect of education on attitude remains when we consider only those who are more insulated from economic competition, that is, respondents who work in combinations of sectors and occupations that have a small share of migrant participation. These results suggest that non-economic channels may also be at work.

We find that education significantly affects values and the cognitive assessment of the role of immigration in host societies. More specifically, we find no effect of education on altruism and the taste for equality, but we do find a positive effect of education on tolerance of diversity and 
on the cognitive assessment of the beneficial effects of immigration in the host country.

Our empirical findings suggest that education functions as an effective policy instrument to affect natives' attitude toward immigrants and increase social cohesion in societies that are subject to large immigration flows. Education affects attitudes not only by providing natives with more secure positions in society but also by changing their values and understanding of the role of migrants in host countries. 


\section{References}

Angrist, J. and Krueger, A. (1991). Does compulsory school attendance affect schooling and earnings? Quarterly Journal of Economics, 106, 979-1014. 3

Boeri, T. (2010). Immigration to the land of redistribution. Economica, 77 (308), 651-687. 1

Borgonovi, F., D'Hombres, B. and Hoskins, B. (2010). Voter turnout, information acquisition and education: Evidence from 15 european countries. The B.E. Journal of Economic Analysis and Policy, 10 (1), 90. 5

BorJAs, G. J. (2003). The labor demand curve is downward sloping: Reexamining the impact of immigration on the labor market. The Quarterly Journal of Economics, 118 (4), 13351374. 4.4 .1

Brunello, G., Fabbri, D. and Fort, M. (2013). The causal effect of education on the body mass: Evidence from europe. Journal of Labor Economics, 31 (1), 195-223. 3, 4.2

—, Fort, M. and Weber, G. (2009). Changes in compulsory schooling, education and the distribution of wages in europe. Economic Journal, 119 (536), 516-539. 3, 3, 6, 4.2

Card, D., Dustmann, C. and Preston, I. (2009). Immigration, Wages, and Compositional Amenities. NBER Working Papers 15521, National Bureau of Economic Research, Inc. 1

Crowne, D. and Marlowe, D. (1964). The Approval Motive. Wiley, New York. 4.4 .2

D’Amuri, F., Ottaviano, G. I. and Peri, G. (2010). The labor market impact of immigration in western germany in the 1990s. European Economic Review, 54 (4), 550-570. 4.4.1

Dustmann, C. and Frattini, T. (2013). The Fiscal Effects of Immigration to the UK. CReAM Discussion Paper Series 1322, Centre for Research and Analysis of Migration (CReAM), Department of Economics, University College London. 4.4.1

- and Preston, I. P. (2001). Attitudes to ethic minorities, ethnic context and location decisions. Economic Journal. 1, 4.4.1 
— and - (2007). Racial and economic factors in attitudes to immigration. The B.E. Journal of Economic Analysis and Policy, 7 (1). 1, 4.4 .2

FACChini, G. and Mayda, A. M. (2012). Individual attitudes towards skilled migration: An empirical analysis across countries. The World Economy, 35 (2), 183-196. 4.4.1

—, - and Mendola, M. (2013). What Drives Individual Attitudes towards Immigration in South Africa? Review of International Economics, 21 (2), 326-341. 4.4.2

—, - - and Puglisi, R. (2009). Illegal immigration and media exposure: Evidence on individual attitudes. CEPR Discussion Papers 7593, C.E.P.R. Discussion Papers. 4.4 .2

Fitzgerald, J., Curtis, K. A. and Corliss, C. L. (2012). Anxious publics: Worries over crime and immigration. Comparative Political Studies, 45, 477-506. 4.4 .2

Foged, M. and PerI, G. (2013). Immigrants and Native Workers: New Analysis Using Longitudinal Employer-Employee Data. NBER Working Papers 19315, National Bureau of Economic Research, Inc. 10, 4.4.3, 5

Hainmueller, J. and Hiscox, M. J. (2007). Educated preferences: Explaining attitudes toward immigration in europe. International Organization, 61, 399-442. 1, 4.1

— and - (2010). Attitudes toward highly skilled and low-skilled immigration: Evidence from a survey experiment. American Political Science Review, 104, 61-84. 1

Jack Citrin, C. M., Donald P. Green and Wong, C. (1997). Public opinion toward immigration reform: The role of economic motivations. The Journal of Politics, 59 (3), 858-881. 1

MAYDA, A. (2006). Who is against immigration? a cross-country investigation of individual attitudes toward immigrants. The Review of Economics and Statistics, 88 (3), 510-530. 1, 4.4.1

Milligan, K., Moretti, E. and Orepoulos, P. (2003). Does education improve citizenship? evidence from the u.s. and the u.k. Journal of Public Economics, 88, 1667-1695. 5

NunZiata, L. (2015). Immigration and crime: Evidence from victimization data. Journal of Population Economics, 28 (3), Forthcoming. 11 
OECD (2013). International Migration Outlook. OECD, Paris. 1

Orepoulos, P. (2006). Estimating average and local average treatment effects of education when compulsory school laws really matter. American Economic Review, 152-175 (1), $1667-$ 1695. 5

O'Rourke, K. H. and Sinnott, R. (2006). The determinants of individual attitudes towards immigration. European Journal of Political Economy, 22 (4), 838-861. 1, 4.4.1

Ottaviano, G. I. P., Peri, G. and Wright, G. C. (2013). Immigration, offshoring, and american jobs. American Economic Review, 103 (5), 1925-59. 4.4.1

Rowthorn, R. (2008). The fiscal impact of immigration on the advanced economies. Oxford Review of Economic Policy, 24 (3), 561-581. 4.4.1

Scheve, K. and Slaughter, M. (2001). Labor-market competition and individual preferences over immigration policy. Review of Economics and Statistics, 83 (1), 133-145. 1, 4.4.1

Staiger, D. and Stock, J. H. (1997). Instrumental variables regression with weak instruments. Econometrica, 65 (3), 557-586. 4.2 
Figure 1: Attitude toward Immigrants of the Same Ethnic Group

\section{Attitude toward Immigrants of Same Ethnic Group}

Source: European Social Survey 2002 - 2010

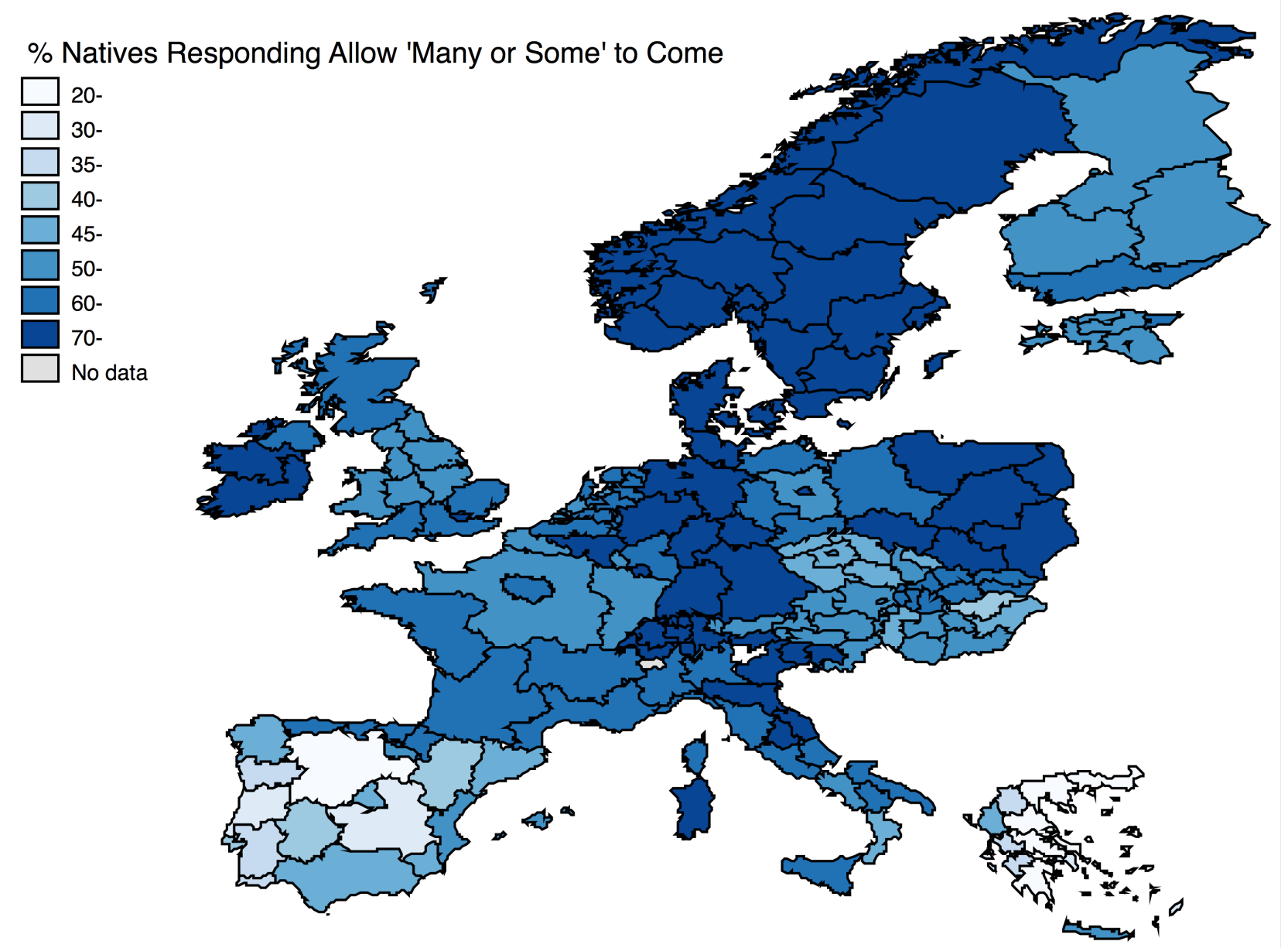

Survey question: "To what extent do you think [country] should allow people of the same race or ethnic group as most [country] people to come and live here?". 
Figure 2: Attitude toward Immigrants of Different Ethnic Group

\section{Attitude toward Immigrants of Different Ethnic Group}

Source: European Social Survey 2002 - 2010

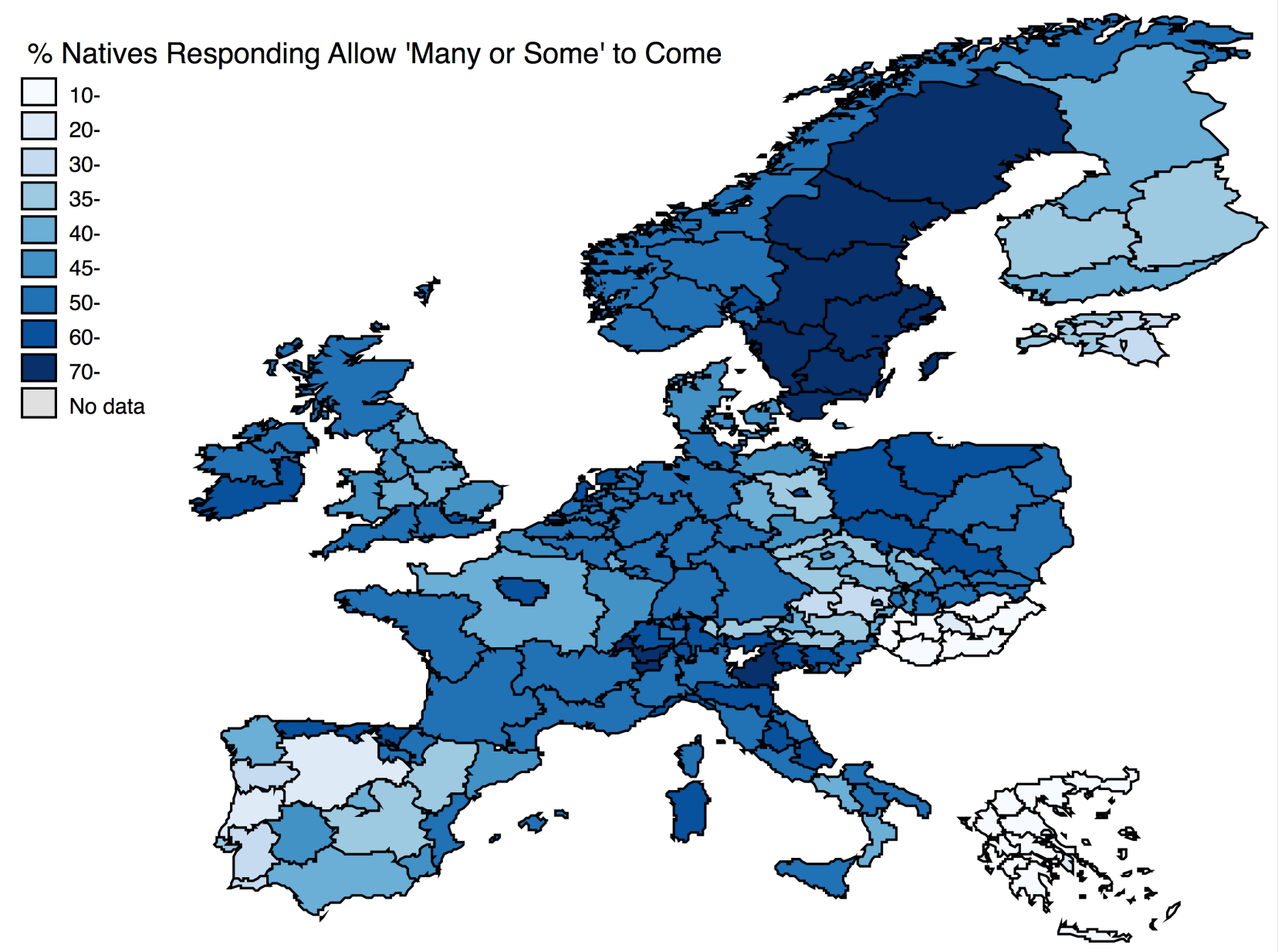

Survey question: "To what extent do you think [country] should allow people of different race or ethnic group from most [country] people to come and live here?". 
Figure 3: Attitude toward Immigrants from Poorer Countries Outside Europe

\section{Attitude toward Immigrants from Poorer Countries}

Source: European Social Survey 2002 - 2010

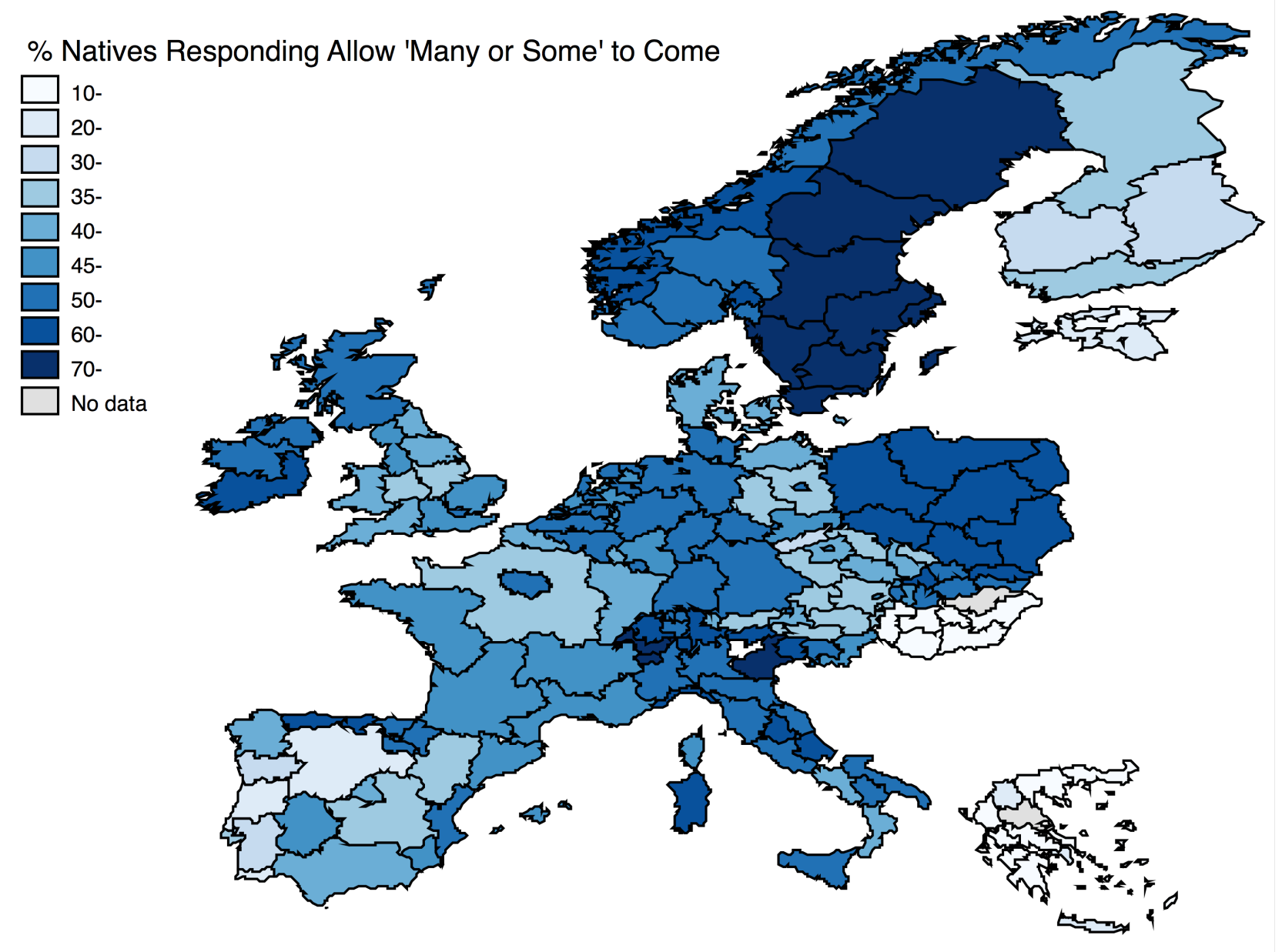

Survey question: "To what extent do you think [country] should allow people from the poorer countries outside Europe to come and live here?". 
Table 1: Summary Statistics

\begin{tabular}{lccc}
\hline Country & \multicolumn{3}{c}{ Mean } \\
& Same Ethn Group & Diff Ethn Group & Poorer Countries \\
\hline BE & 2.78 & 2.46 & 2.47 \\
DE & 2.89 & 2.52 & 2.47 \\
DK & 3.05 & 2.55 & 2.42 \\
ES & 2.52 & 2.45 & 2.46 \\
FI & 2.63 & 2.31 & 2.24 \\
FR & 2.64 & 2.45 & 2.36 \\
GB & 2.58 & 2.37 & 2.29 \\
GR & 2.32 & 1.83 & 1.80 \\
IT & 2.81 & 2.60 & 2.58 \\
NL & 2.68 & 2.56 & 2.47 \\
PT & 2.22 & 2.13 & 2.11 \\
SE & 3.24 & 3.15 & 3.13 \\
\hline
\end{tabular}

Source: European Social Survey, 2002-2010. The variables range from (1) to (4). A higher value for each of the three variables implies a more favorable attitude versus immigrants. 


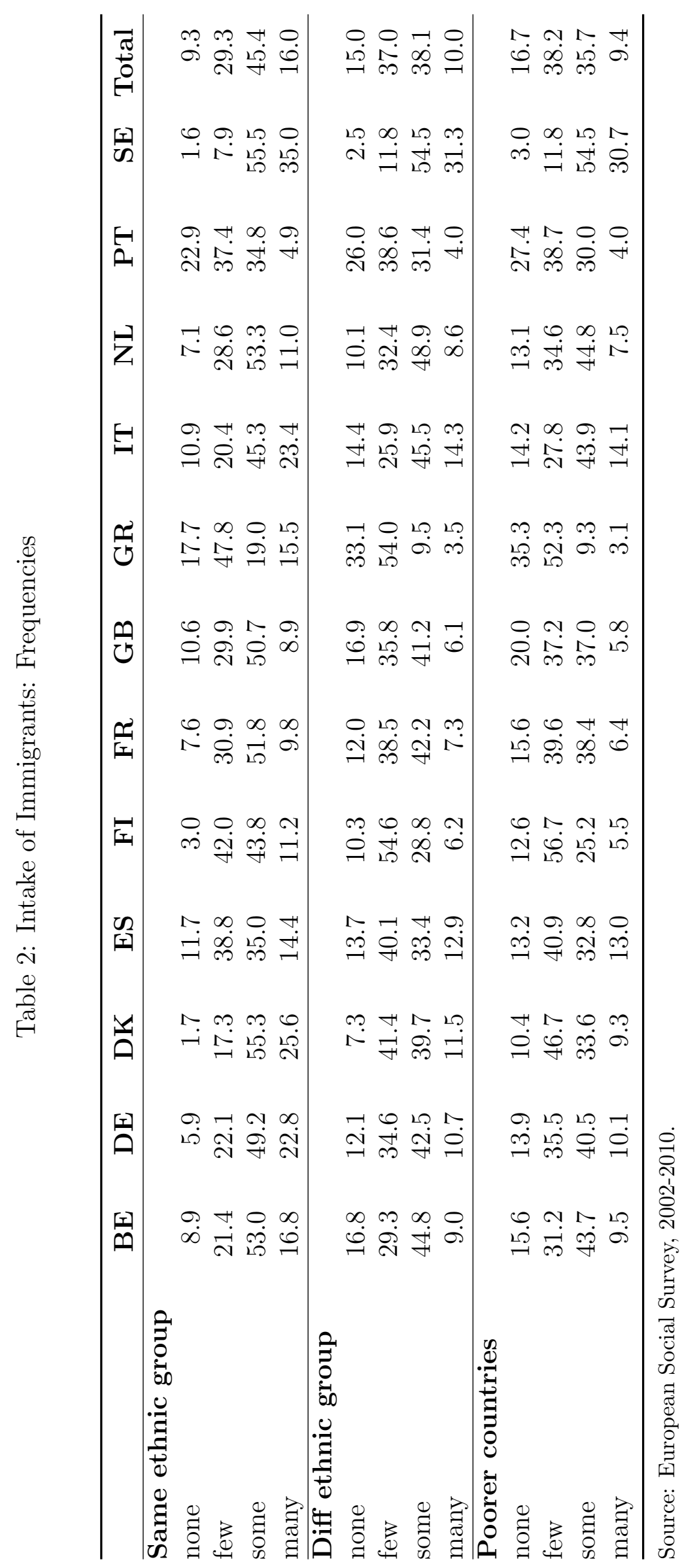


Table 3: Summary Statistics

\begin{tabular}{lccccccc}
\hline \hline & $\begin{array}{c}\text { Foreign } \\
\text { born \% }\end{array}$ & $\begin{array}{c}\text { Ratio } \\
\text { Primary }\end{array}$ & $\begin{array}{c}\text { Ratio } \\
\text { Tertiary }\end{array}$ & $\begin{array}{c}\text { Ratio } \\
\text { Unemployed }\end{array}$ & $\begin{array}{c}\text { Ratio } \\
\text { HH size }\end{array}$ & $\begin{array}{c}\text { Ratio kids } \\
\text { below14 }\end{array}$ & $\begin{array}{c}\text { Ratio } \\
\text { Income }\end{array}$ \\
\hline BE & 16.62 & 1.37 & 0.92 & 2.32 & 1.11 & 1.64 & 0.98 \\
DE & 8.12 & 3.41 & 0.71 & 1.96 & 1.20 & 1.93 & 0.88 \\
DK & 6.75 & 1.00 & 1.19 & 2.04 & & & \\
ES & 8.24 & 0.83 & 0.85 & 1.64 & 1.09 & 1.89 & 0.74 \\
FI & 3.44 & 1.63 & 0.90 & 2.12 & & & \\
FR & 13.65 & 1.66 & 0.85 & 1.62 & 1.15 & 1.43 & 0.91 \\
GR & 9.46 & 1.14 & 0.69 & 1.38 & 1.08 & 1.74 & \\
IT & 8.93 & 0.95 & 0.93 & 1.49 & 1.03 & 1.86 & 0.73 \\
NL & 11.85 & 1.45 & 0.88 & 2.21 & 1.07 & 1.46 & 0.97 \\
PT & 6.49 & 0.66 & 1.97 & 1.47 & 1.02 & 1.61 & 1.06 \\
SE & 13.48 & 1.71 & 1.07 & 2.15 & & & \\
UK & 12.63 & 0.82 & 1.10 & 1.15 & 1.16 & 1.56 & \\
\hline \hline
\end{tabular}

Source: Labour Force Survey, 2002-2010. Columns 1 shows the share of migrants in each country. Column 2 reports the ratio of the share of migrants with primary education to the share of natives with primary education. Column 3 reports the same ratio but for tertiary education while column 4 displays the ratio of unemployed migrants to unemployed natives. Column 5 reports the ratio of the average household size of natives to the migrant average household size. Column 6 displays a similar ratio but in terms of the number of kids below 14 per household. Column 7 shows the ratio of the average income decile of natives to the average income decile of migrants, when available. 


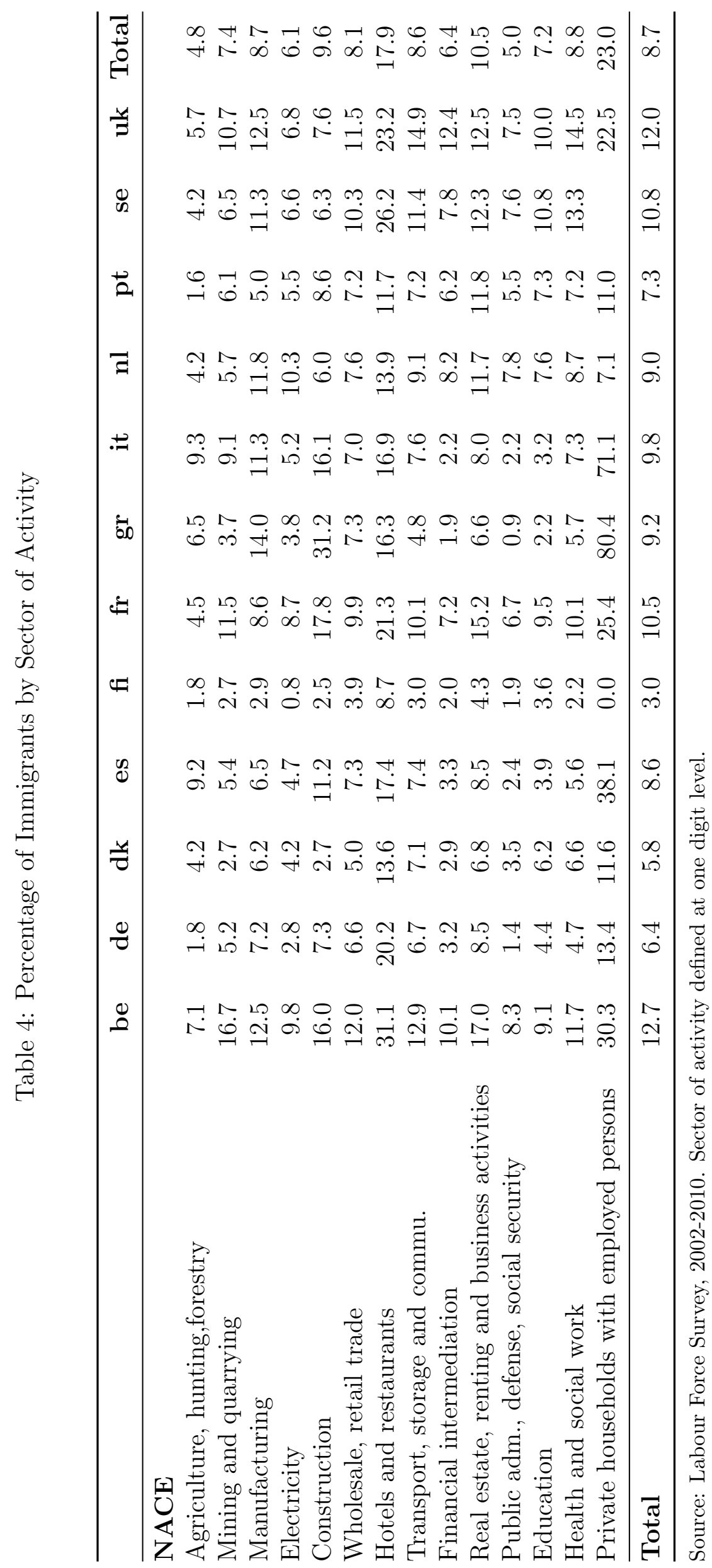




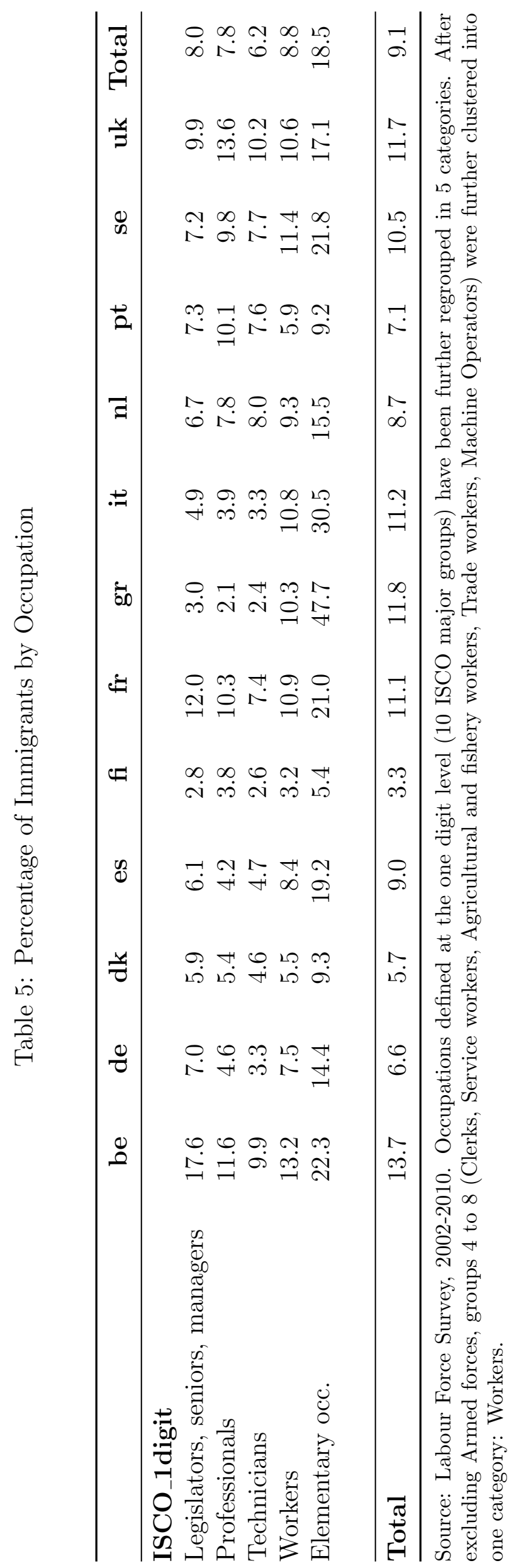


Table 6: OLS and Probit Regressions of the Effect of Education on Attitudes Toward Immigrants

\begin{tabular}{|c|c|c|c|}
\hline \multicolumn{4}{|c|}{ Same Ethnic Group } \\
\hline & $(1)$ & $(2)$ & $(3)$ \\
\hline & OLS Full Sample & OLS Restricted Sample & Probit \\
\hline EDUC & $\begin{array}{c}0.024 \\
(48.84)\end{array}$ & $\begin{array}{c}0.023 \\
(28.85)\end{array}$ & $\begin{array}{c}0.026 \\
(27.13)\end{array}$ \\
\hline Observations & 66,933 & 21,949 & 21,949 \\
\hline \multicolumn{4}{|c|}{ Different Ethnic Group } \\
\hline & $(1)$ & $(2)$ & $(3)$ \\
\hline & OLS Full Sample & OLS Restricted Sample & Probit \\
\hline EDUC & $\begin{array}{c}0.026 \\
(51.83)\end{array}$ & $\begin{array}{c}0.027 \\
(33.23)\end{array}$ & $\begin{array}{c}0.031 \\
(31.00)\end{array}$ \\
\hline Observations & 66,933 & 21,949 & 21,949 \\
\hline \multicolumn{4}{|c|}{ Poorer Countries Outside Europe } \\
\hline & $(1)$ & $(2)$ & $(3)$ \\
\hline & OLS Full Sample & OLS Restricted Sample & Probit \\
\hline EDUC & $\begin{array}{c}0.023 \\
(45.77)\end{array}$ & $\begin{array}{c}0.024 \\
(28.87)\end{array}$ & $\begin{array}{c}0.026 \\
(27.61)\end{array}$ \\
\hline Observations & 66,933 & 21,949 & 21,949 \\
\hline
\end{tabular}

Dependent variables are dummy variables equal to one if the respondent thinks that "some" or "many" people from, respectively, (i) the same ethnic/race group, (ii) a different ethnic/race group and (iii) poorer countries outside Europe, should be allowed to come and live in her country of residence. The dummies are equal to zero if the respondent thinks that "few" or "none" immigrants should be allowed in. The additional controls include demographical variables (age, gender), country, area of residence and survey dummies as well as country-specific quadratic trends. We have also included major regional dummies for Germany and the UK (East Germany, Northern Ireland and Scotland fixed effects). For Portugal, for which three reforms are used when presenting the IV estimates, we introduce country-reformspecific birth cohort trends. The model in column 1 is estimated using OLS on the full sample, column 2 is OLS on the restricted sample used in the IV regressions, column 3 is a Probit. Robust t-statistics are reported in brackets. 
Table 7: Instrumental Variable Regressions of the Effect of Education on Attitudes Toward Immigrants

\begin{tabular}{|c|c|c|c|c|c|}
\hline \multicolumn{6}{|c|}{ Same Ethnic Group } \\
\hline & (1) & $(2)$ & $(3)$ & $(4)$ & $(5)$ \\
\hline & IV & IV bandwith 5 & IV bandwith 9 & No Trend & Placebo \\
\hline \multirow[t]{2}{*}{ EDUC } & 0.088 & 0.090 & 0.052 & 0.058 & 0.333 \\
\hline & $(2.90)$ & $(2.69)$ & $(1.95)$ & $(2.62)$ & $(0.30)$ \\
\hline $\mathrm{N}$ & & 16110 & 27700 & 21949 & 21387 \\
\hline \multicolumn{6}{|c|}{ Different Ethnic Group } \\
\hline & $(1)$ & (2) & (3) & (4) & $(5)$ \\
\hline & IV & IV bandwith 5 & IV bandwith 9 & No Trend & Placebo \\
\hline \multirow[t]{2}{*}{ EDUC } & 0.097 & 0.082 & 0.080 & 0.066 & -0.415 \\
\hline & $(3.25)$ & $(2.84)$ & $(3.08)$ & $(3.04)$ & $(-0.27)$ \\
\hline $\mathrm{N}$ & 21949 & 16110 & 27700 & 21949 & 21387 \\
\hline \multicolumn{6}{|c|}{ Poorer Countries Outside Europe } \\
\hline & $(1)$ & $(2)$ & $(3)$ & $(4)$ & $(5)$ \\
\hline & IV & IV bandwith 5 & IV bandwith 9 & No Trend & Placebo \\
\hline \multirow[t]{2}{*}{ EDUC } & 0.100 & 0.105 & 0.070 & 0.050 & -0.114 \\
\hline & $(3.24)$ & $(3.21)$ & $(2.75)$ & $(2.30)$ & $(-0.18)$ \\
\hline $\mathrm{N}$ & 21949 & 16110 & 27700 & 21949 & 21387 \\
\hline \multicolumn{6}{|l|}{ First Stage } \\
\hline & (1) & $(2)$ & (3) & (4) & $(5)$ \\
\hline & IV & IV bandwith 5 & IV bandwith 9 & No Trend & Placebo \\
\hline REFORM & 0.349 & 0.371 & 0.348 & 0.423 & \\
\hline \multirow[t]{2}{*}{ FAKED REFORM } & & & & & -0.033 \\
\hline & & & & & $(-0.30)$ \\
\hline $\mathrm{N}$ & 21949 & 16110 & 27700 & 21949 & 21387 \\
\hline
\end{tabular}

Dependent variables are dummy variables equal to one if the respondent thinks that "some" or "many" people from, respectively, (i) the same ethnic/race group, (ii) a different ethnic/race group and (iii) poorer countries outside Europe, should be allowed to come and live in her country of residence. The dummies are equal to zero if the respondent thinks that "few" or "none" immigrants should be allowed in. The additional controls include demographical variables (age, gender), country, area of residence and survey dummies as well as country-specific quadratic trends. We have also included major regional dummies for Germany and the UK (East Germany, Northern Ireland and Scotland fixed effects). For Portugal, for which three reforms are used, we introduce country-reform-specific birth cohort trends. The model in column 1 is estimated instrumenting Education with compulsory schooling reforms, considering individuals who were born up to 7 years before or after the first cohort affected by the last reform in compulsory schooling. Columns 2 and 3 display the IV estimates obtained by using bandwidths of different length, i.e. respectively $+/-5$ years and $+/-9$ years. Column 4 corresponds to the IV estimates without country-specific quadratic trends. Column 5 displays IV estimates when a placebo reform generated randomly from a uniform distribution over the time span 1947 - 1999 is used to instrument Education and while considering individuals who were born up to 7 years before or after the first cohort affected by the fake reform. The first stage regressions for each model are reported at the bottom of the table. Cluster robust t-statistics at country-cohort of birth level are reported in brackets. 


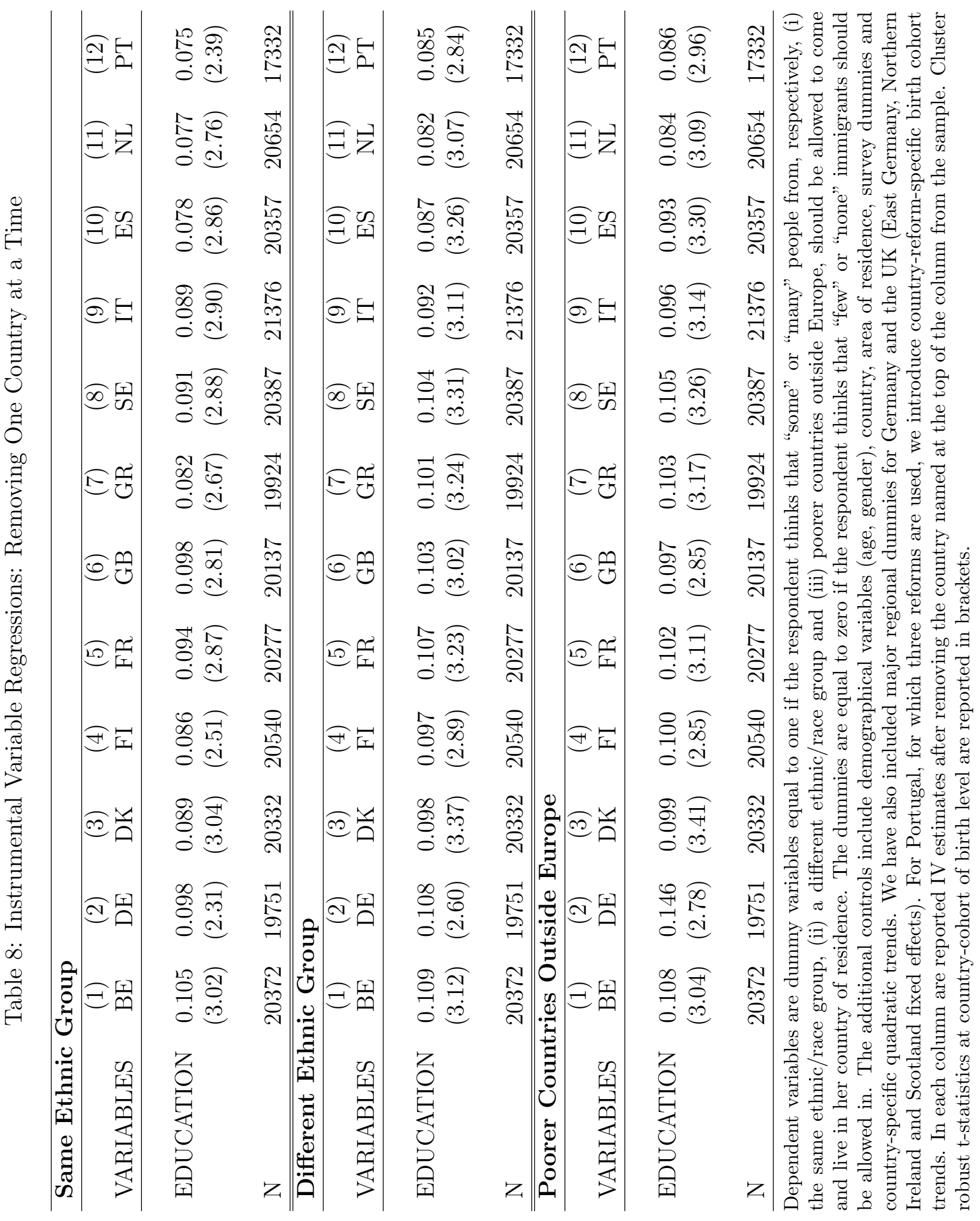


Table 9: Instrumental Variable Regressions of the Effect of Education on Labour Market Status

\begin{tabular}{lllllll}
\hline & $(1)$ & $(2)$ & $(3)$ & $(4)$ & $(5)$ & $(6)$ \\
& $\begin{array}{l}\text { Unempl., } \\
\text { Short } \\
\text { Term, } \\
\text { Welfare }\end{array}$ & $\begin{array}{l}\text { Low } \\
\text { Skilled } \\
\text { Occup. }\end{array}$ & $\begin{array}{l}\text { Highest } \\
\text { Imm. } \\
\text { Sectors }\end{array}$ & $\begin{array}{l}\text { High Imm. } \\
\text { Sector } \\
\text { /Occup. }\end{array}$ & $\begin{array}{l}\text { High Imm. } \\
\text { Occup. }\end{array}$ & $\begin{array}{l}\text { High Imm. } \\
\text { Sector } \\
\text { /Occup. } \\
\text { /Unempl. }\end{array}$ \\
\hline \multirow{2}{*}{ EDUC } & -0.104 & -0.083 & -0.022 & 0.007 & 0.014 & -0.030 \\
& $(-2.69)$ & $(-2.87)$ & $(-0.77)$ & $(0.17)$ & $(0.39)$ & $(-0.97)$ \\
& 19691 & 19691 & 19691 & 19691 & 19691 & 19691 \\
\hline
\end{tabular}

In column (1) the dependent variable takes the values one if the individual reports to be unemployed, or employed with a short term contract or to be living in a household whose main source of income is provided by the welfare system, zero otherwise. In column (2), the dependent variable is a discrete variable equal to one if the individuals is working (or was working if unemployed) in a low skill occupation (workers and elementary occupations), zero otherwise. In columns (3), the dependant variable is a discrete variable equal to one if the individual is working (or was working if unemployed) in one of the sectors (digit 1 level) with the highest share of migrants in the country. In column (4), the dependent variables takes the value one if the individuals is working (or was working if unemployed) in a combination of sector and occupation (five broad categories) with a high penetration of migrants, zero otherwise. A sector/occupation is considered with a high penetration rate if the share of migrants is above the share of migrants at the country level. The outcome variable in column (5) is defined similarly as in column (4) but the penetration rate is defined only at the occupational level (digit 2 level). In column (6) the dependent variables take the value one if the individual is working in a sector/occupation with a high share of migrants (variable in column (4) equal to one) or a high unemployment rate (i.e. higher than the country average). The unemployment rate relative to combinations of sectors and occupations is calculated from European Social Survey data while the migrants' penetration rate is obtained from Labour Force Survey data. The additional controls include demographical variables (age, gender), country, area of residence, survey dummies and countryspecific quadratic trends. In the case of UK and Germany, we have also included major regional dummies (East Germany, Northern Ireland and Scotland fixed effects). For Portugal, for which three reforms are used, we introduce country-reform-specific birth cohort trends. In each column are reported IV estimates. Cluster robust t-statistics at country-cohort of birth level are reported in brackets. 
Table 10: Instrumental Variable Regressions of the Effect of Education on Attitudes Toward Immigrants among Individuals Insulated from Economic Competition

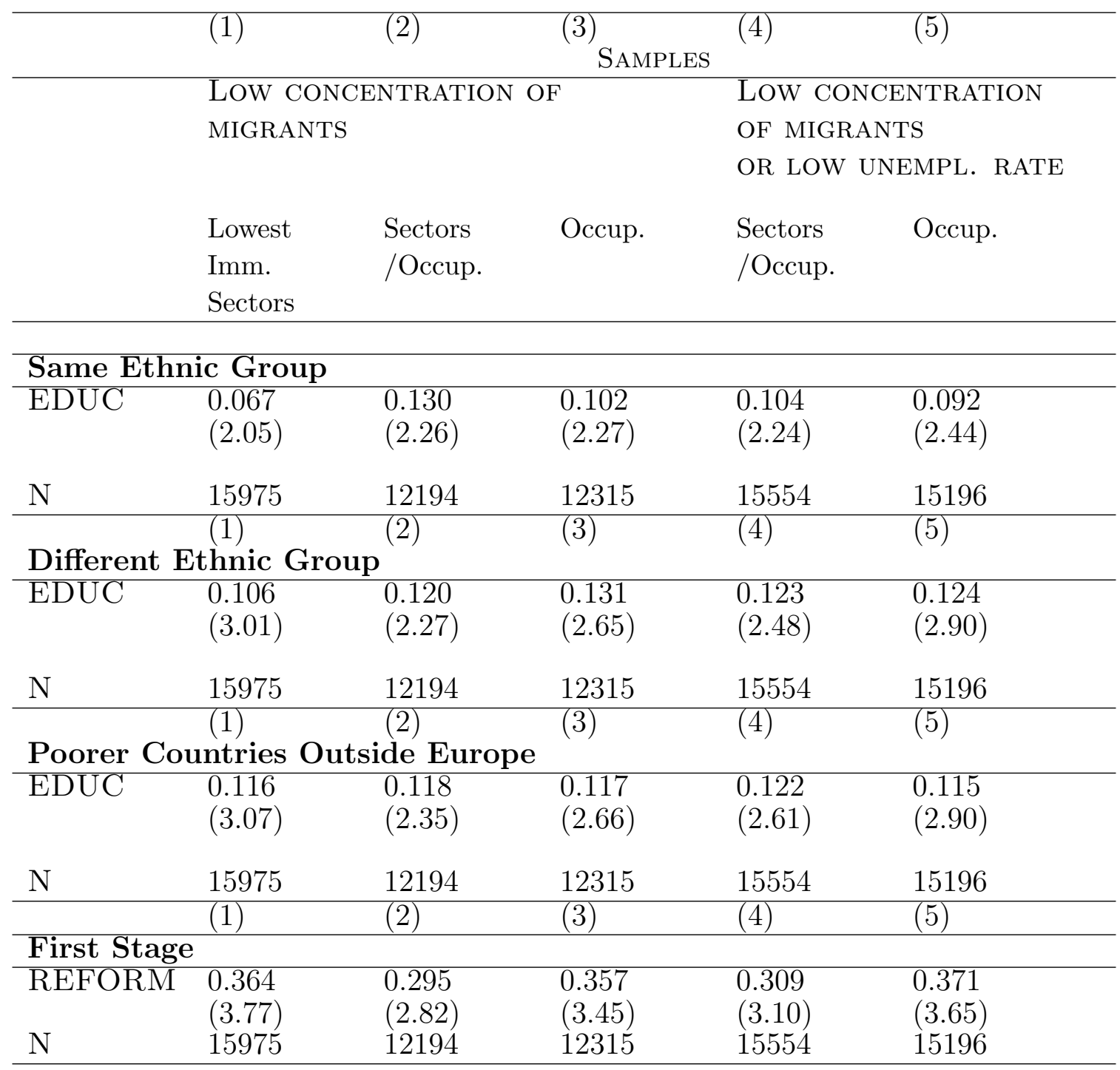

Dependent variables are dummy variables equal to one if the respondent thinks that "some" or "many" people from, respectively, (i) the same ethnic group, (ii) a different ethnic group and (iii) poorer countries outside Europe, should be allowed to come and live in her country of residence. The dummies are equal to zero if the respondent thinks that "few" or "none" immigrants should be allowed in. In the case of UK and Germany, we have also included major regional dummies (East Germany, Northern Ireland and Scotland fixed effects). In the first three columns the sample is composed of individuals working (or who were working if unemployed) in sectors and/or occupations with a low penetration of migrants. The share of migrants is defined as low if it is below the mean share of migrants at the country level except in column 1 where we exclude the 4 sectors with the highest share of migrants in each country. In the last two columns we consider only individuals in sectors and/or occupations with a low penetration of migrants or low unemployment rate. The additional controls include demographical variables (age, gender), country, area of residence, survey dummies and country-specific quadratic trends. In the case of UK and Germany, we have also included major regional dummies (East Germany, Northern Ireland and Scotland fixed effects). For Portugal, for which three reforms are used, we introduce country-reform-specific birth cohort trends. In each column is reported the effect of education while instrumenting education with compulsory schooling reforms and considering a sample of individuals who were born up to 7 years before or after the first cohort affected by the last reform in compulsory schooling. Cluster robust t-statistics at country-cohort of birth level are displayed in brackets. 
Table 11: Instrumental Variable Regressions of the Effect of Education on nonEconomic Outcomes

\begin{tabular}{lccccc}
\hline VARIABLES & $\begin{array}{c}(1) \\
\text { Altruism }\end{array}$ & $\begin{array}{c}(2) \\
\text { Equality }\end{array}$ & $\begin{array}{c}(3) \\
\text { Diversity }\end{array}$ & $\begin{array}{c}(4) \\
\text { Cultural } \\
\text { Enrichment }\end{array}$ & $\begin{array}{c}(5) \\
\text { Better } \\
\text { Country }\end{array}$ \\
\hline EDUCATION & -0.019 & 0.059 & 0.078 & 0.074 & 0.065 \\
& $(-0.70)$ & $(1.44)$ & $(2.72)$ & $(2.30)$ & $(2.23)$ \\
$\mathrm{N}$ & 21251 & 21239 & 21675 & 21949 & 21949 \\
\hline
\end{tabular}

In column (1), the dependent variable is a discrete variable equal to one if the individuals reports that it is "very much" like him to help people and care for others well being, zero otherwise. In column (2), the outcome variable is equal to one if the individual reports that treating every person equally in the world and believing that everyone should have equal opportunities in life is "very much" what he thinks. In column (3), the dependent variable takes the value one if the individual declares that he strongly agrees or agrees that gays and lesbians are free to live life as they wish, zero otherwise. In column (4), the dependent variable is a discrete variable equal to one if the individual believes that the country's cultural life is enriched by immigrants, zero otherwise while in column (5) the dependent variable is equal to one when the respondent thinks that immigrants make country a better place to live, zero otherwise. In each column we report the effect of education while instrumenting education with compulsory schooling reforms and considering a sample of individuals who were born up to 7 years before or after the first cohort affected by the last reform in compulsory schooling. Cluster robust t-statistics at country-cohort of birth level are displayed in brackets. 
Appendix A: ESS Data and Country Summary Statistics 
Table A1: ESS Data: Summary Statistics, Full Sample

\begin{tabular}{lrrrr}
\hline Country & Obs & Age & $\begin{array}{r}\text { Share of } \\
\text { Males }\end{array}$ & $\begin{array}{r}\text { Years of } \\
\text { Education }\end{array}$ \\
\hline \hline BE & 6785 & 49.04 & 50.00 & 12.86 \\
DE & 10746 & 51.12 & 51.42 & 13.54 \\
DK & 6312 & 51.03 & 52.15 & 13.74 \\
ES & 7528 & 48.13 & 49.83 & 11.34 \\
FI & 5487 & 50.93 & 50.52 & 12.59 \\
FR & 5964 & 49.73 & 46.71 & 12.23 \\
GB & 8792 & 50.89 & 45.77 & 13.01 \\
GR & 6674 & 48.48 & 43.39 & 10.63 \\
IT & 2017 & 48.08 & 49.28 & 10.87 \\
NL & 8059 & 50.57 & 46.22 & 13.18 \\
PT & 8086 & 51.76 & 41.29 & 7.57 \\
SE & 6689 & 50.45 & 51.92 & 12.66 \\
\hline
\end{tabular}

European Social Survey, 2002-2010. The sample is composed of individuals aged between 22 and 80 included, citizens of the host country where the ESS survey took place and whose parents are also nationals.

Table A2: ESS Data: Summary Statistics, Restricted Sample

\begin{tabular}{lrrrr}
\hline Country & Obs & Age & $\begin{array}{r}\text { Share of } \\
\text { Males }\end{array}$ & $\begin{array}{r}\text { Years of } \\
\text { Education }\end{array}$ \\
\hline \hline BE & 2040 & 38.45 & 51.84 & 14.09 \\
DE & 2680 & 43.79 & 50.90 & 13.95 \\
DK & 2089 & 60.05 & 52.75 & 12.97 \\
ES & 2156 & 49.75 & 49.12 & 11.64 \\
FI & 1591 & 43.98 & 51.48 & 14.15 \\
FR & 1774 & 53.53 & 47.80 & 11.74 \\
GB & 2490 & 48.66 & 46.75 & 13.42 \\
GR & 2131 & 42.75 & 41.01 & 11.96 \\
IT & 597 & 52.89 & 49.75 & 10.45 \\
NL & 1656 & 69.34 & 47.64 & 10.99 \\
PT & 5937 & 49.90 & 41.08 & 7.82 \\
SE & 2083 & 56.29 & 51.18 & 12.64 \\
\hline
\end{tabular}

European Social Survey, 2002-2010. The restricted sample is composed of individuals aged between 22 and 80 included, citizens of the host country where the ESS survey took place, whose parents are also nationals and who are born up to 7 years before or after the reforms of compulsory education used for the IV estimates. 
Table A3: Attitudes Toward Immigrants from Poorer Countries: Average Responses by Country and Year

\begin{tabular}{lcccccc}
\hline & \multicolumn{7}{c}{ ESS round } \\
Country & $\mathbf{2 0 0 2}$ & $\mathbf{2 0 0 4}$ & $\mathbf{2 0 0 6}$ & $\mathbf{2 0 0 8}$ & $\mathbf{2 0 1 0}$ & Total \\
& & & & & & \\
\hline BE & 2.48 & 2.40 & 2.49 & 2.58 & 2.40 & 2.47 \\
DE & 2.57 & 2.29 & 2.32 & 2.61 & 2.55 & 2.47 \\
DK & 2.44 & 2.33 & 2.42 & 2.44 & 2.46 & 2.42 \\
ES & 2.55 & 2.61 & 2.49 & 2.29 & 2.43 & 2.46 \\
FI & 2.33 & 2.20 & 2.20 & 2.34 & 2.13 & 2.24 \\
FR & 2.33 & 2.35 & 2.33 & 2.38 & 2.38 & 2.36 \\
GB & 2.34 & 2.35 & 2.28 & 2.30 & 2.18 & 2.29 \\
GR & 1.87 & 1.91 & & 1.79 & 1.66 & 1.80 \\
IT & 2.69 & 2.50 & & & & 2.58 \\
NL & 2.51 & 2.41 & 2.38 & 2.55 & 2.49 & 2.47 \\
PT & 2.15 & 2.03 & 2.09 & 2.13 & 2.15 & 2.11 \\
SE & 3.07 & 3.05 & 3.14 & 3.18 & 3.22 & 3.13 \\
\hline
\end{tabular}

Source: European Social Survey 2002-2010. The variables range from 1 to 4 . A higher value for each of the three variables implies a more favorable attitude versus immigrants.

Table A4: Attitudes Toward Immigrants from Different Ethnic Groups: Average Responses by Country and Year

\begin{tabular}{lcccccc}
\hline & \multicolumn{7}{c}{ ESS round } \\
Country & $\mathbf{2 0 0 2}$ & $\mathbf{2 0 0 4}$ & $\mathbf{2 0 0 6}$ & $\mathbf{2 0 0 8}$ & $\mathbf{2 0 1 0}$ & Total \\
& & & & & & \\
\hline BE & 2.45 & 2.42 & 2.48 & 2.55 & 2.40 & 2.46 \\
DE & 2.55 & 2.36 & 2.41 & 2.67 & 2.60 & 2.52 \\
DK & 2.47 & 2.45 & 2.55 & 2.60 & 2.69 & 2.55 \\
ES & 2.57 & 2.60 & 2.46 & 2.32 & 2.42 & 2.45 \\
FI & 2.29 & 2.23 & 2.28 & 2.45 & 2.30 & 2.31 \\
FR & 2.38 & 2.40 & 2.45 & 2.49 & 2.50 & 2.45 \\
GB & 2.36 & 2.41 & 2.37 & 2.39 & 2.31 & 2.37 \\
GR & 1.86 & 1.93 & & 1.85 & 1.70 & 1.83 \\
IT & 2.71 & 2.51 & & & & 2.60 \\
NL & 2.53 & 2.49 & 2.47 & 2.67 & 2.65 & 2.56 \\
PT & 2.15 & 2.07 & 2.11 & 2.17 & 2.18 & 2.13 \\
SE & 3.05 & 3.09 & 3.16 & 3.21 & 3.25 & 3.15 \\
\hline
\end{tabular}

Source: European Social Survey 2002-2010. The variables range from 1 to 4 . A higher value for each of the three variables implies a more favorable attitude versus immigrants. 
Table A5: Attitudes Toward Immigrants from the Same Ethnic Group: Average Responses by Country and Year

\begin{tabular}{lcccccc}
\hline & & \multicolumn{5}{c}{ ESS round } \\
Country & $\mathbf{2 0 0 2}$ & $\mathbf{2 0 0 4}$ & $\mathbf{2 0 0 6}$ & $\mathbf{2 0 0 8}$ & $\mathbf{2 0 1 0}$ & Total \\
& & & & & & \\
\hline BE & 2.69 & 2.76 & 2.82 & 2.88 & 2.72 & 2.78 \\
DE & 2.85 & 2.74 & 2.80 & 3.07 & 2.99 & 2.89 \\
DK & 2.93 & 3.02 & 3.11 & 3.07 & 3.11 & 3.05 \\
ES & 2.65 & 2.68 & 2.53 & 2.33 & 2.53 & 2.52 \\
FI & 2.64 & 2.59 & 2.62 & 2.74 & 2.58 & 2.63 \\
FR & 2.58 & 2.63 & 2.63 & 2.68 & 2.64 & 2.64 \\
GB & 2.62 & 2.65 & 2.57 & 2.57 & 2.50 & 2.58 \\
GR & 2.16 & 2.27 & & 2.35 & 2.49 & 2.32 \\
IT & 2.85 & 2.79 & & & & 2.81 \\
NL & 2.64 & 2.66 & 2.63 & 2.78 & 2.72 & 2.68 \\
PT & 2.26 & 2.20 & 2.17 & 2.21 & 2.26 & 2.22 \\
SE & 3.17 & 3.19 & 3.24 & 3.29 & 3.34 & 3.24 \\
\hline
\end{tabular}

Source: European Social Survey 2002-2010. The variables range from 1 to 4 . A higher value for each of the three variables implies a more favorable attitude versus immigrants. 
Appendix B: Compulsory Reforms in Europe 


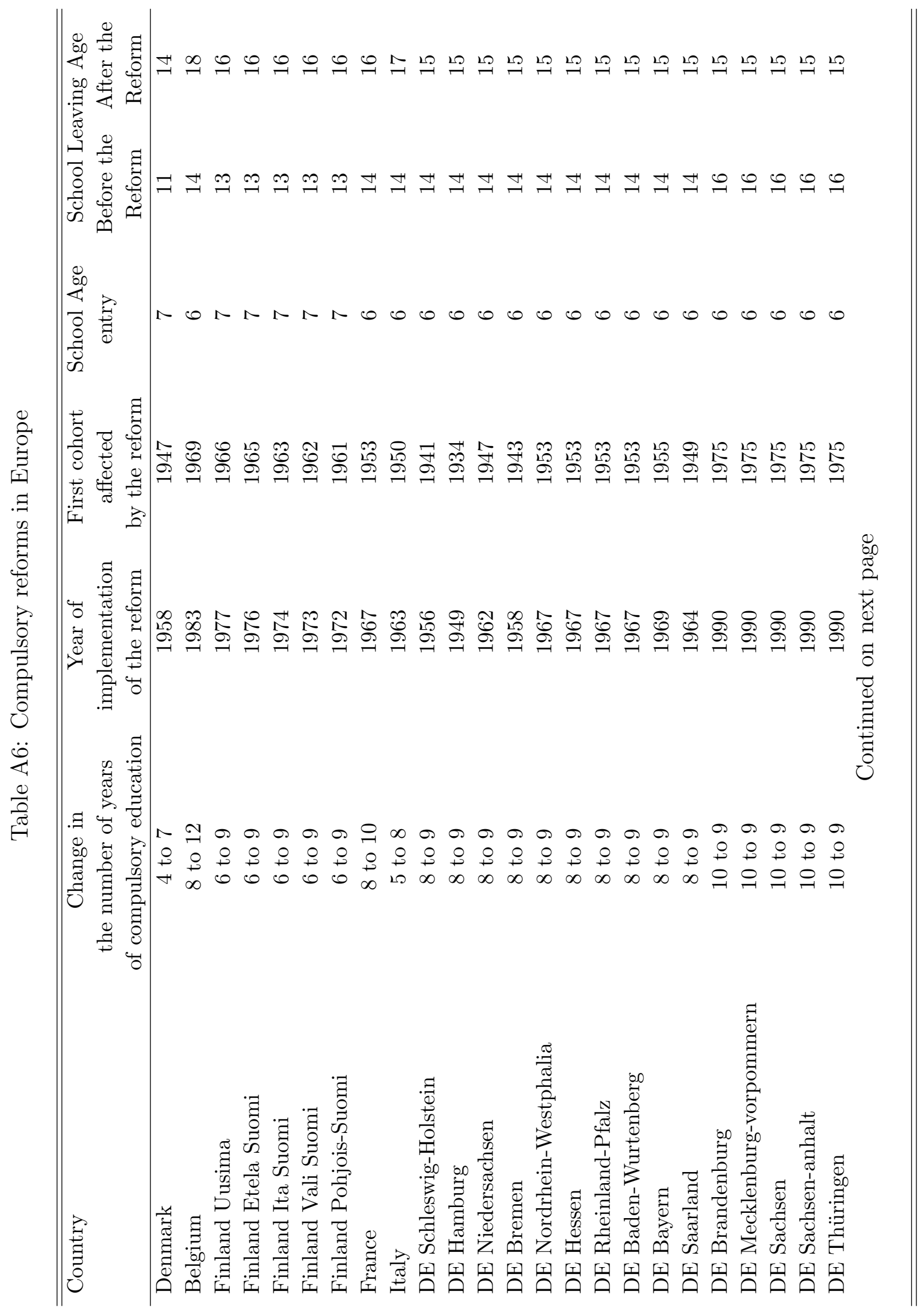




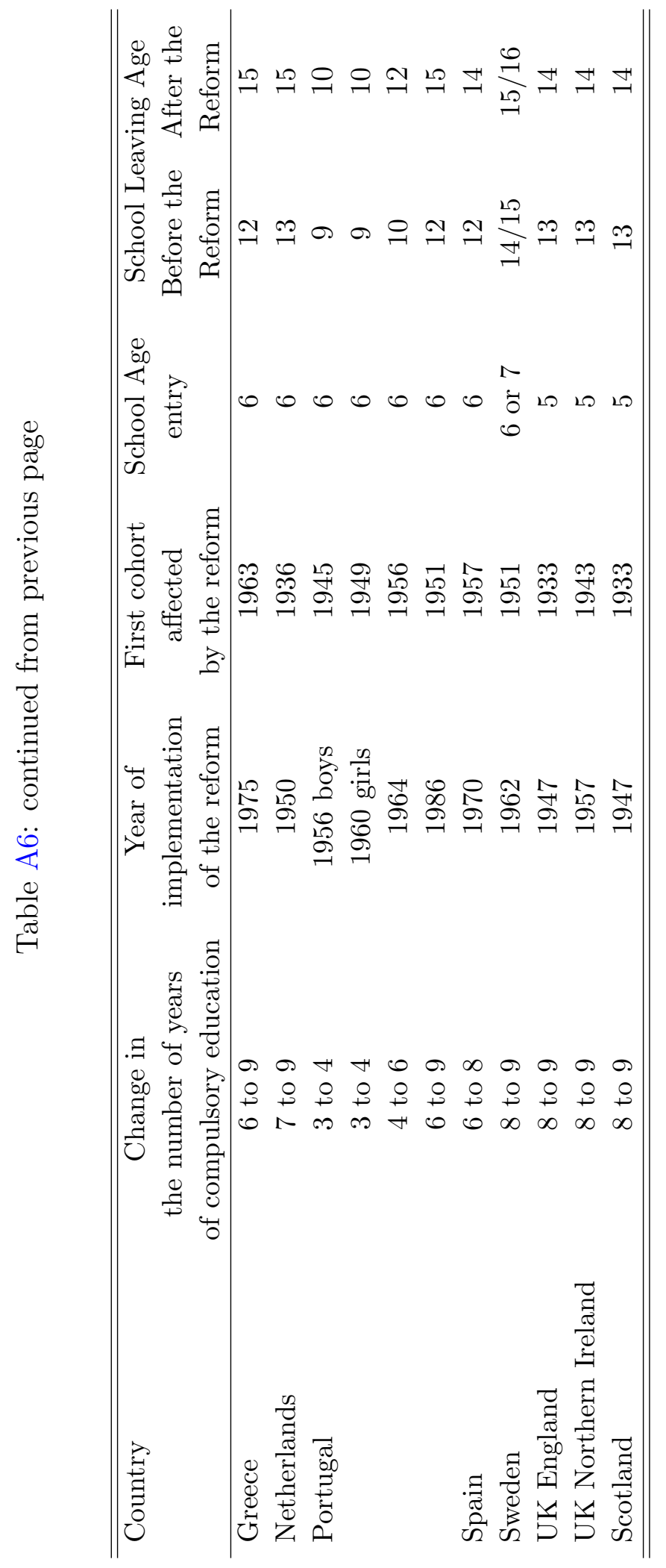

